\title{
Activation of stylolites as conduits for overpressured fluid flow in dolomitized platform carbonates
}

\author{
J.D. Martín-Martín ${ }^{1 *}$, E. Gomez-Rivas², D. Gómez-Gras ${ }^{3}$, A. Travé1, R. Ameneiro¹, D. \\ Koehn ${ }^{4}$ and P.D. Bons ${ }^{5}$ \\ ${ }^{1}$ Departament de Mineralogia, Petrologia i Geologia Aplicada, Facultat de Geologia, Universitat de Barcelona \\ (UB), Martí i Franquès s/n, 08028 Barcelona, Spain \\ ${ }^{2}$ Geology and Petroleum Geology, School of Geosciences, University of Aberdeen, King's College AB24 3UE \\ Aberdeen, Scotland, UK \\ ${ }^{3}$ Departament de Geologia, Universitat Autònoma de Barcelona, 08193 Bellaterra, Spain \\ ${ }^{4}$ School of Geographical and Earth Sciences, University of Glasgow, Gregory Building, Lillybank Gardens, G12 \\ $8 Q Q$, Glasgow, $U K$ \\ ${ }^{5}$ Department of Geosciences, Eberhard Karls University Tübingen, Wilhelmstr. 56, 72074 Tübingen, Germany \\ "Corresponding author (e-mail: juandiegomartin@ub.edu)
}

\begin{abstract}
This study investigates the late Aptian-early Albian platform carbonates of the Benicàssim area (Maestrat Basin, Spain) in order to assess the relationship between bedparallel stylolites and the flow of diagenetic fluids during dolomitization and late hydrothermal alteration. Dolomite and burial dolomite and calcite cements were studied by a combination of field geology and standard petrographic and isotope analysis. The results indicate that dolostones are closely associated with seismic-scale synsedimentary faults. Dolostones preferentially replace grain-dominated facies and typically show wavy dolomitizing fronts that mostly correspond to bed-parallel stylolites. The dolostones are corroded and contain bedparallel pores that are filled with hydrothermal saddle dolomite and late blocky calcite cements. This calcite cement frequently engulfs clasts of the host dolomite suggesting that hydraulic brecciation likely associated with overpressured fluid occurred. Results indicate that stylolites play a key role in the distribution of dolostones and subsequent hydrothermal mineralization. During the replacement stage, stylolites acted as baffles for the dolomitzing fluids controlling lateral fluid flow and resulting in the stratabound dolostone distribution. During the postdolomitization stage, stylolites became preferred pathways for overpressured hydrothermal corrosive and mineralizing fluids that likely came from the underlying basement, and increased bed-parallel stylolitic porosity and probably permeability as well.
\end{abstract}

Keywords: dolomitization, hydrothermal cementation, stylolites, fault, overpressured fluid

This manuscript is accepted for publication in the Geological Society of London Special Issue on Small to subseismic-scale reservoir deformation, edited by Ashton, M. et al.

This is an author version of the article. For the final copy-edited version, please visit:

http://sp.lyellcollection.org/ 
Prediction of subseismic-scale deformation structures is of primary importance for carbonate reservoir management, since they often play a fundamental role in controlling the rock's bulk permeability and can therefore determine pathways for fluids and hence reservoir quality (e.g. Nelson 2001; Agar \& Geiger 2014). In recent years, most attention has been paid to subseismicscale fracture networks, fracture corridors and fault-damage zones due to their capacity of significantly altering the permeability of carbonate rocks (e.g. Davy et al. 2006; Gross \& Eyal, 2007; Benedicto \& Schultz 2009; Baqués et al. 2014). The accurate prediction of the geometries, distribution and properties of these structures is very challenging because their evolution during diagenesis and deformation is notably complex and difficult to constrain. This is mainly due to the high reactivity and complex mechanical behaviour of carbonates, which can result in (1) an increase of fracture permeability due to fracture opening by reactivation, hydrofracturing, propagation or dissolution (Caine et al. 1996; Agosta et al. 2010) or (2) a permeability decrease associated with mechanical fracture closing, formation of gouge and other grain size reduction processes or fracture sealing by mineral precipitation (Laubach et al. 2010; Bons et al. 2012). Surprisingly, significantly less attention has been paid to stylolites and stylolite networks as structures affecting fluid flow and reservoir quality, although they are ubiquitous in most carbonate formations (e.g. Paganoni et al. 2015). Stylolites are rough dissolution surfaces that form as a consequence of intergranular pressure-solution (e.g. Stockdale 1922; Park \& Schot 1968; Merino 1992; Koehn et al. 2007). Bed-parallel stylolites, also termed diagenetic stylolites, form due to layer-normal compression during burial and compaction. Stylolites are very common structures in many reservoir rock types, and typically form networks presenting a variety of geometries depending on their amplitude, spacing, connectivity or anastomosis (Vandeginste \& John 2013; Ben-Itzhak et al. 2014). It has historically been assumed that stylolites are generally barriers to fluid flow (e.g. Nelson 1981; Finkel \& Wilkinson 1990; Dutton \& Willis 1998; Alsharhan \& Sadd 2000), since they typically contain insoluble residues that are impermeable. However, other studies report that porosity can increase at their flanks and tips, therefore allowing fluid circulation (Carozzi \& von Bergen 1987; Van Geet et al. 2001). More recently, Heap et al. (2014) suggested that stylolites may play no role in determining fluid flow. It seems logical that stylolites can act as conduits for fluid flow at some stage during the evolution of a basin, since they are discontinuities in the rock, act as weak planes and therefore be opened during further episodes of tectonic activity and fluid circulation. For example, bed-parallel stylolites can potentially be opened when they are parallel to the principal compressive stress $\sigma_{l}$, such as for example in reservoirs with horizontal or subhorizontal layers subjected to horizontal compression (e.g. in a strike-slip regime, Gomez-Rivas et al. 2014a; or when the least principal stress $\sigma_{3}$ is vertical). Another case that can result in stylolite opening is when interstitial fluid pressure increases due to processes such as rock decompression or heating (e.g. Staude et al. 2009) or when more fluid enters than leaves the system (e.g. in high pressure cells; Hilgers et al. 2006). These situations are common during the diagenetic evolution of carbonate-bearing basins, and therefore it can be expected that stylolites may have different hydraulic conductivity properties through geologic time, depending on the burial, tectonic and fluid circulation histories. Although stylolites are ubiquitous structures that affect major carbonate reservoirs, their evolution and influence on permeability and reservoir quality have not been systematically studied. One reason is that it can be very difficult to acquire significant amounts of data from real reservoirs, because stylolites in the subsurface are only observable in drill core just allowing the 
observation of a very small proportion of the system and basically in one dimension. Aspects of stylolite networks such as their lateral continuity, connectivity or lateral property variations (e.g. amplitude) can hardly be determined within drill cores. Therefore, the study of stylolite networks from outcrop analogues is a key issue in order to better constrain their evolution through time, their impact on further diagenetic events (dissolution, cementation, replacement) and their role in determining reservoir quality and fluid flow behaviour during production.

This paper reports the role of stylolites in the burial dolomitization and subsequent hydrothermal corrosion that affects the Benassal Fm (Late Aptian-early Albian) platform carbonates located in Benicàssim (Maestrat Basin, E Spain). Previous works dealing with the dolostones of the Benicàssim area focused on the study of the replacement process (MartínMartín et al. 2013; Corbella et al. 2014; Gomez-Rivas et al. 2014b; Martín-Martín et al. 2015), and concentrated on well-exposed stratabound dolostones cropping out in areas relatively far away from the seismic-scale faults that acted as feeders for dolomitizing fluids. However, the areas closer to the fault zones are not equally well documented, although these represent areas of high interest. Therefore, this study focusses on a newly reported outcrop from the Benicàssim area (La Ferradura outcrop) and aims to: (1) Document seismic- and subseismic-scale controls on the formation of the dolostones and subsequent burial alterations; (2) Discuss the mechanisms that resulted in stylolite opening and sealing; (3) Discuss the distribution and extent of the fluid flow, and the potential link to reservoir quality at the basin scale. The results obtained in this study can provide new insights into the evolution of porosity and permeability in shallow-marine carbonates that can be taken into account for exploration and production of equivalent reservoirs in the Middle East and other parts of the World.

\section{GEOLOGICAL SETTING}

\section{Structure and sediments}

The Maestrat Basin (E Spain) developed as part of the Iberian Rift System in the Iberian Plate during the Late Jurassic-Early Cretaceous (Salas et al. 2001). The structure of the basin is controlled by dominant NW-SE faults and NE-SW faults, configuring a system of fault-bounded blocks that accommodated the deposition of up to $6 \mathrm{~km}$ thick pile of Lower Cretaceous sediments (Fig. 1). The Early Cretaceous faults were reactivated during the Alpine compression with strike-slip and oblique-slip movements, and in some parts recorded strong dip-slip offsets again, during the Neogene extension period (Gomez-Rivas et al. 2012). Some of these faults are inherited from Hercynian structures (e.g. Liesa \& Simon, 2009). According to Antolín-Tomás et al. (2007), seismic reflection profiles along the Maestrat Basin reveal that (i) the E-W to NW-SE set of large-scale extensional faults flatten at about $3 \mathrm{~km}$ within the crust (e.g. Liesa et al. 2006), probably having a detachment in the upper levels of the Paleozoic rocks; (ii) the N-S to NE-SW set of seismic-scale faults have detachments between 10 and $15 \mathrm{~km}$, reaching the base of the crust (e.g. Roca 1996).

The study area is located in the southeastern margin of the Maestrat Basin, where the intersection of the W-E Campello and the NNE-SSW Benicàssim faults accommodated a 2200m-thick Lower Cretaceous succession (Martín-Martín et al. 2013) (Figs 1a-b). Most of this 
succession, approximately $1500 \mathrm{~m}$, corresponds to the Late Aptian-earliest Albian Benassal Fm (Fig. 2), which is characterized by shallow-water marine carbonate deposits, containing orbitolinid-, rudist- and coral-rich facies (Riding \& Tomás, 2006; Tomás et al. 2008; Skelton \& Gili 2012). The age of the formation has been partially calibrated with ammonites (MorenoBedmar et al. 2010; Bover-Arnal et al. 2010; García et al. 2014).

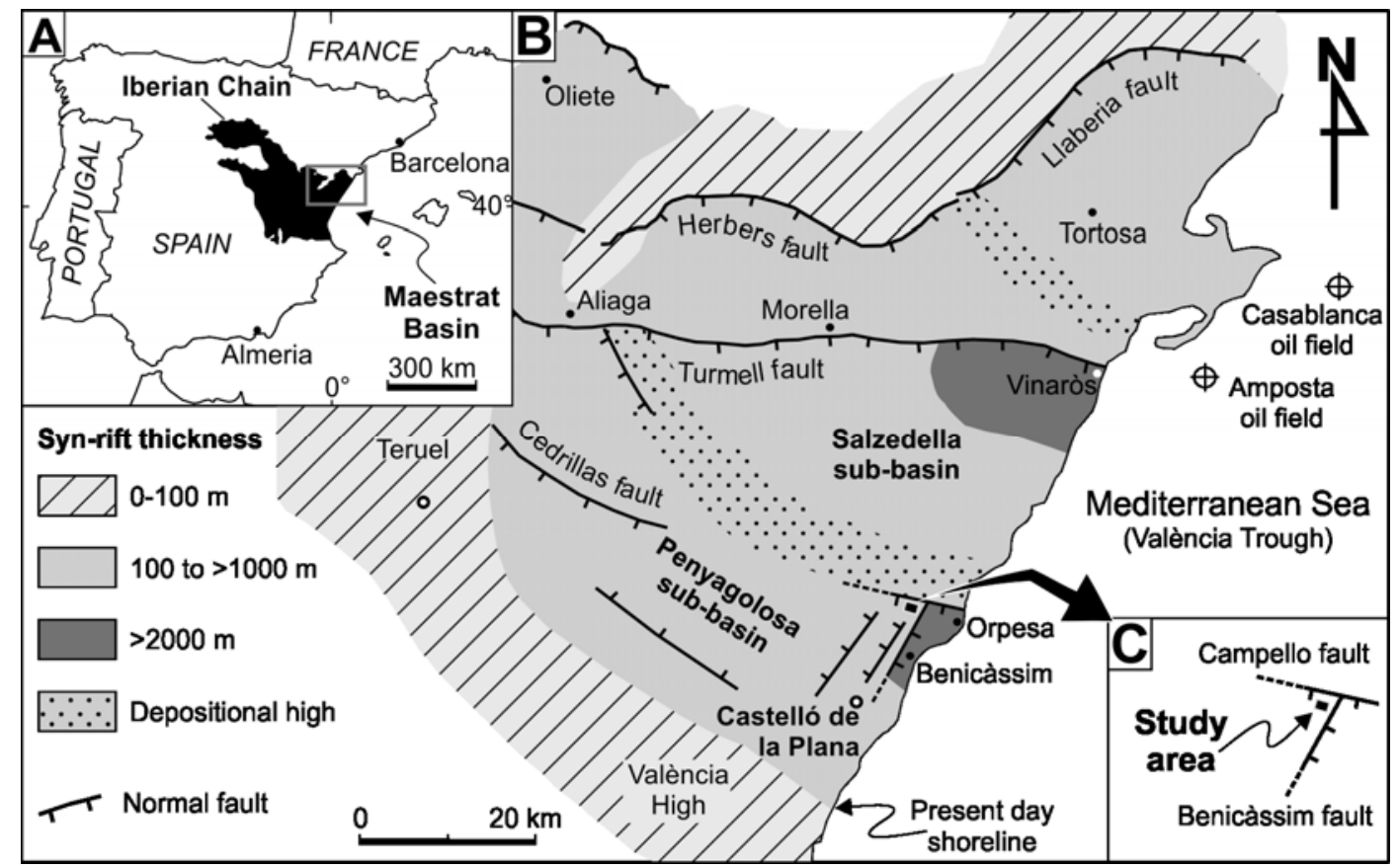

Fig. 1. (a) Map showing the location of the Maestrat Basin in the Iberian Peninsula. (b) Paleogeographic map of the Maestrat Basin during the Late Jurassic to Early Cretaceous rift stage showing most the important faults and the thickness of syn-rift deposits (modified after Salas et al. 2001). (c) Detail of indicated area in b showing the location of the study area (see Figure 4) and its relationship to regional Benicàssim and Campello Faults.

\section{Fault-controlled dolostones}

The Benassal Fm is partially dolomitized in close association with the aforementioned regional faults, constituting a world-class case study of fault-controlled dolomitization and associated Mississippi Valley-Type (MVT) mineralization recently reported in the literature (Martín-Martín et al. 2013, 2015; Corbella et al. 2014; Gomez-Rivas et al. 2014b). These previous studies reported dolostone bodies of tens of meters thick that extend several $\mathrm{km}$ away from seismic-scale faults with a dominant stratabound distribution. Dolostones preferentially replace limestone beds with grainy textures and a low degree of early calcite cementation, and also those beds located between tight, mud-dominated and strongly stylolitized limestone facies.

The dolostones are characterized by a burial paragenesis formed by the replacement of limestones, corrosion, saddle dolomite and calcite cementation, and MVT mineralization (Fig. 2a; Martín-Martín et al. 2015). Mimetic textures in replacive dolomite crystal mosaics evidence that the replacement of the host limestones took place after some compaction, fracturing and cementation, and thus during burial, but before the emplacement of the MVT deposits. Stylolites 
mostly predate the replacement of the host limestones (Figs 2a-b). Accordingly, burial curves indicate that dolomitization of the Benassal Fm limestones occurred at depths $<1 \mathrm{~km}$ (Fig. 2c). Martín-Martín et al. (2015) concluded that the dolomitization of the Benassal Fm generated abundant intercrystalline porosity that was subsequently destroyed by burial saddle dolomite and calcite cements, and in particular by calcite cements during uplift.

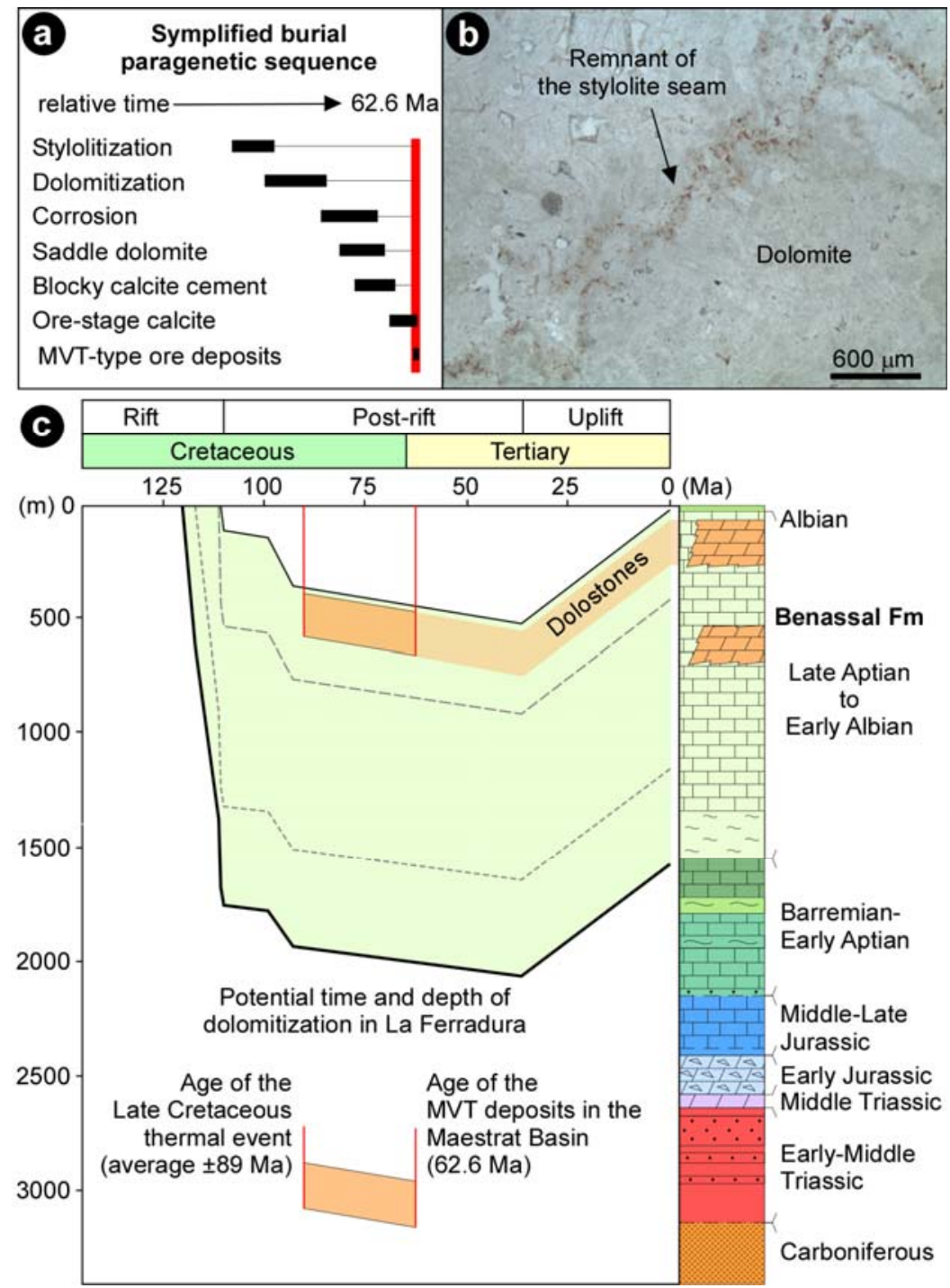

Fig. 2. (a) Regional stratigraphic section and decompacted burial curve of the Benassal Formation in the Benicàssim area showing most probable time and depth of dolomitization (Based on Martín-Martín et al. 2015). Note that the formation of the dolomite is placed between 90-62 Ma (red vertical lines), corresponding 91 Ma to the average age of the regional Late Cretaceous thermal event (Salas et al. 2001) and 62.6 Ma to the age of the Mississippi ValleyType deposits in the Maestrat Basin (Grandía et al. 2000). Grey lines within the Benassal Fm denote TransgressiveRegressive (T-R) sequences. Rift and post-rift cycles follow Salas et al. (2001). (b) Simplified paragenetic sequence of the Benassal Fm showing major diagenetic alterations related to dolomitization and MVT mineralization. (c) Photomicrograph of the replacive dolomite crystal mosaic showing the trace of a stylolite highlighted by remnants of the clay seam (diffused light). 


\section{Dolomitizing and mineralizing fluids}

Based on crush-leach analysis of dolomite from elsewhere in the Maestrat Basin (Grandia et al. 2000) and stable C-O isotopy and Sr-isotopes of replacive dolostones from the Benicàssim area (Fig 3; Gomez-Rivas et al. 2014b), dolomitizing fluids were interpreted as seawater-derived brines that interacted with and were heated in the underlying Permian-Triassic rocks and Paleozoic basement. Such fluids were later delivered through the regional fault system to the country rock by a pervasive hydrothermal fluid flow system, probably governed by thermal convection.

Following the dolomitization of the host limestones, high temperature hydrothermal acidic fluids preceding the formation of MVT ore deposits promoted the corrosion of the dolostones and generated abundant post-replacement porosity (Fig. 3; Martín-Martín et al. 2015). This new pore system was subsequently cemented by saddle dolomite and blocky calcite cement, probably associated with the formation of Mississippi Valley Type $\mathrm{Pb}-\mathrm{Zn}$ ore deposits in the nearby Campello mine. The hydrothermal character of these fluids was corroborated by homogenisation temperatures between 134 and $190^{\circ} \mathrm{C}$ in the blocky calcite cement, well above the expected $<50^{\circ} \mathrm{C}$ ambient temperature for a maximum burial depth of $<1 \mathrm{~km}$ (Fig. 2a).

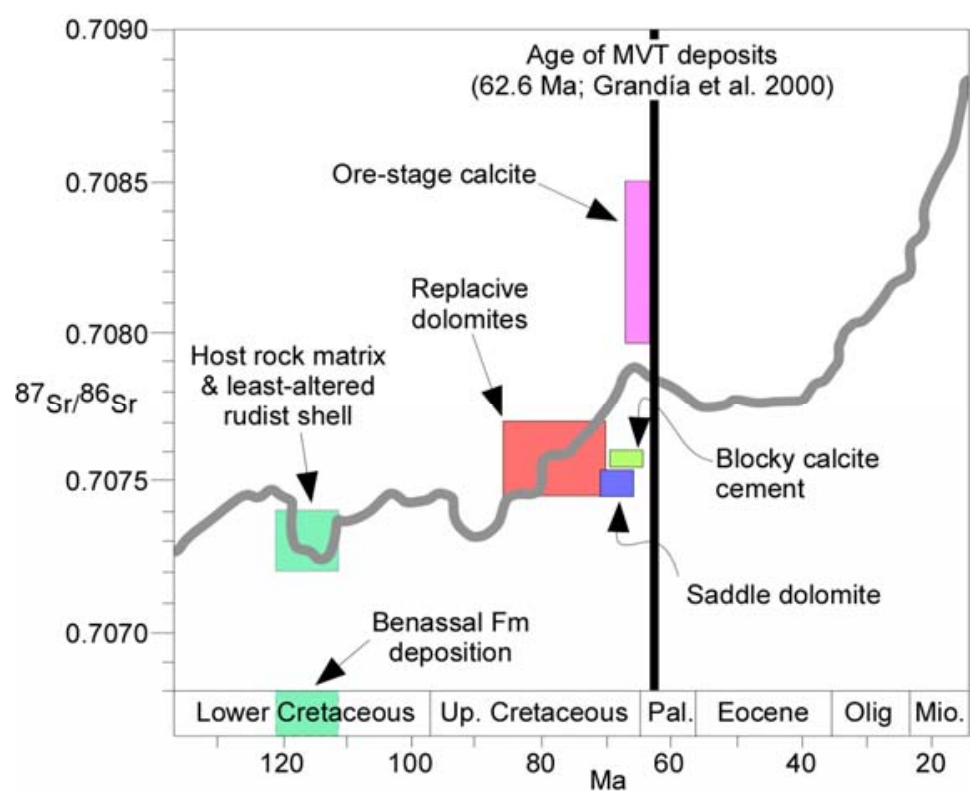

Fig. 3. Sr-isotopic signal of burial calcite and dolomite phases from the Benicàssim area (Martín-Martín et al. 2015) plotted on the seawater Sr-isotope curve (grey line) of Jones \& Jenkins (2001). Note that the formation of the replacive dolomite is placed between 91-62.5 following Fig. 2. Ore-stage calcite Sr-isotopic signature after GomezRivas et al. (2014b). 
Martín-Martín et al., in press. Activation of stylolites as conduits for overpressured fluid flow in dolomitized platform carbonates. Geological Society of London Special Publication

\section{Regional high-temperature event}

Several high-temperature processes reported in the literature indicate a Late Cretaceous thermal event in the NE part of the Iberian Plate and in the Maestrat Basin that ultimately caused the abnormal geothermal gradients $\left(>30 \mathrm{C}^{\circ} / \mathrm{km}\right)$ and very likely the dolomitization of Lower Cretaceous limestones and MVT mineralization. Among others, these high temperature processes include: (i) the formation of $\mathrm{Hg}$-Sb-bearing ore deposits $\left(140-180{ }^{\circ} \mathrm{C}\right)$ during the Santonian ( $85 \pm 3 \mathrm{Ma}$ ) (Tritlla \& Solé 1999; Tritlla \& Cardellach 2003); (ii) very low-grade metamorphism in Permian-Triassic rocks $\left(300^{\circ} \mathrm{C}\right)$ in a period between the Barremian $(127 \pm 3$ Ma) and the Turonian (93 $\pm 3 \mathrm{Ma}$ ) (Martín-Martín et al. 2005; Martín-Martín et al. 2009), and (iii) the presence of hydrothermal MVT ore deposits along a NW-SE transect in the Maestrat Basin in the early Paleocene (62.6 $\pm 0.7 \mathrm{Ma}$ ) (Grandia et al. 2000; Grandia et al. 2003). At the large scale, these high temperature peaks are presumably associated with the presence of a pluton below the Iberian Chain that formed in relation to the opening of the North Atlantic (Salas et al. 2005). Moreover, these high temperature peaks are time-equivalent to those that resulted in the dolomitization of the Basque Cantabrian Basin (López-Horgue et al. 2010; Shah et al. 2010; Swennen et al. 2012; Dewit et al. 2014), and thus are presumably associated with the same large scale geodynamic event.

\section{METHODS}

The dolostones of the La Ferradura outcrop have been characterized by means of fieldwork, satellite imagery (Google Earth and Terrasit) and outcrop photo interpretations (Figs 4-5). A 196-m-thick lithostratigraphic section was logged through the dolostone body in order to characterize limestone facies and dolomitization fronts (Fig. 6). Field descriptions include lithology, skeletal and non-skeletal components and carbonate rock textures, following the classification of Dunham (1962) and Embry \& Klovan (1971). 40 rock samples were collected both along the logged section and perpendicular to the fault planes. Samples include limestones, dolostones, and late saddle dolomite and calcite cements. 35 polished slabs and 40 thin sections were examined with a Zeiss Axiophot petrographic microscope. Samples were analyzed with a Technosyn Cold Cathode Luminescence microscope (Model 8200 MkII) with standard operation conditions of $15-18 \mathrm{kV}$ and 300-350 $\mu \mathrm{A}$. Detailed petrographic analysis was performed with a scanning electron microscope Quanta 200 FEI equipped with an X-ray spectrometer.

Oxygen and carbon isotope composition was analysed in 34 selected samples that include replacive dolomites and late saddle dolomite and calcite cements. The isotopic signature of the host limestone was obtained by analyzing one sample of the micrite matrix. Samples were drilled from rock slabs with a micro-drill equipped with 0.5 to $1 \mathrm{~mm}$ diameter bits. Powdered calcite and dolomite samples were reacted with phosphoric acid for 3 and 15 min respectively in vacuum at $70^{\circ} \mathrm{C}$. The evolved $\mathrm{CO}_{2}$ was analyzed in a Thermo Finnigan MAT-252 mass spectrometer. Results were corrected and expressed in \%o relative to standard Vienna Pee Dee Belemnite (V-PDB), with a deviation reported of $\pm 0.02 \%$ for $\delta^{13} \mathrm{CV}_{\mathrm{V} \text {-PDB }}$ and of $\pm 0.04 \%$ for $\delta^{18} 0 \mathrm{~V}$ PDB. 


\section{RESULTS}

\section{Dolostone association with faults}

The dolostones at the La Ferradura outcrop form a main 100-m-thick, east-to-west tabular brown coloured body that extends over $550 \mathrm{~m}$ between two bounding normal faults (Figs 4, 5ab). The East Fault strikes NE-SW and has an offset of hundreds of meters, separating the dolostones in the footwall from stratigraphically younger limestones in the hanging wall. This East Fault is subparallel to the regional NNE-SSW Benicàssim Fault, which is an Early Cretaceous syn-sedimentary fault that controlled the deposition of the Late Aptian-earliest Albian Benassal Fm.

The West Fault strikes N-S and has an offset of tens of meters, separating the dolostone from equivalent host limestones towards the west (Figs. 4-5). In spite of the low offset, the host limestones are not replaced in the footwall block except for a small patch, indicating that this fault was already a barrier for dolomitizing fluids at time of replacement. The dolostone body is divided in two parts by the N-S striking Central Fault and segmented by several sub-parallel outcrop-scale faults (\#1 to \#4; Figs. 4, 5a-b). The N-S striking fault system is oblique to the synsedimentary NW-SE Campello Fault, which is located $2 \mathrm{~km}$ north of the study area.

\section{Limestone and dolostone facies}

Field observations indicate that the La Ferradura dolostones replace an interval of limestones between the East and West bounding faults with a quite constant stratigraphic limit (Figs 4, 5a-b). The first half of the sedimentary succession is composed of several bed sets that contain rudist bivalves- and Chondrodonta-bearing muddy facies (Fig. 6). Individual bed sets are characterized by meter-scale strata containing fragments of rudist bivalves and minor Chondrodonta (rudist wackestones to floatstones) capped by beds with the same components in live position (rudist and Chondrodonta boundstones) (Figs 4-5-6a). The second half of the succession, which is partially replaced with dolostones, is composed of coral wackestones, and peloidal- and orbitolinid-rich facies (peloidal packstones to grainstones, and peloidal and orbitolinid packstones to grainstones) (Figs 4-5-6a).

The dolostones are brown to orange in colour due to their partial alteration (i.e. calcitization) in outcrop exposures. Dolomitizing fronts are sharp and undulate, and commonly follow bedding planes or bed-parallel stylolites (i.e., stratabound). In some cases, the dolomitizing fronts crosscut the strata following the aforementioned outcrop-scale faults. The limestone beds (stringers) located within the dolostones are metre- to decametre-thick and are mainly composed of (i) coral wackestones with nodular bedding and wave-like stylolites (Figs 6b-c), and (ii) the lower and marly part of the peloidal packstones to grainstones facies (Fig. 6). At the La Ferradura outcrop these stringers are frequent between the two bounding faults but less abundant in the vicinity of the West Fault zone where the limestones only appear as small-sized patches. 
Martín-Martín et al., in press. Activation of stylolites as conduits for overpressured fluid flow in dolomitized platform carbonates. Geological Society of London Special Publication
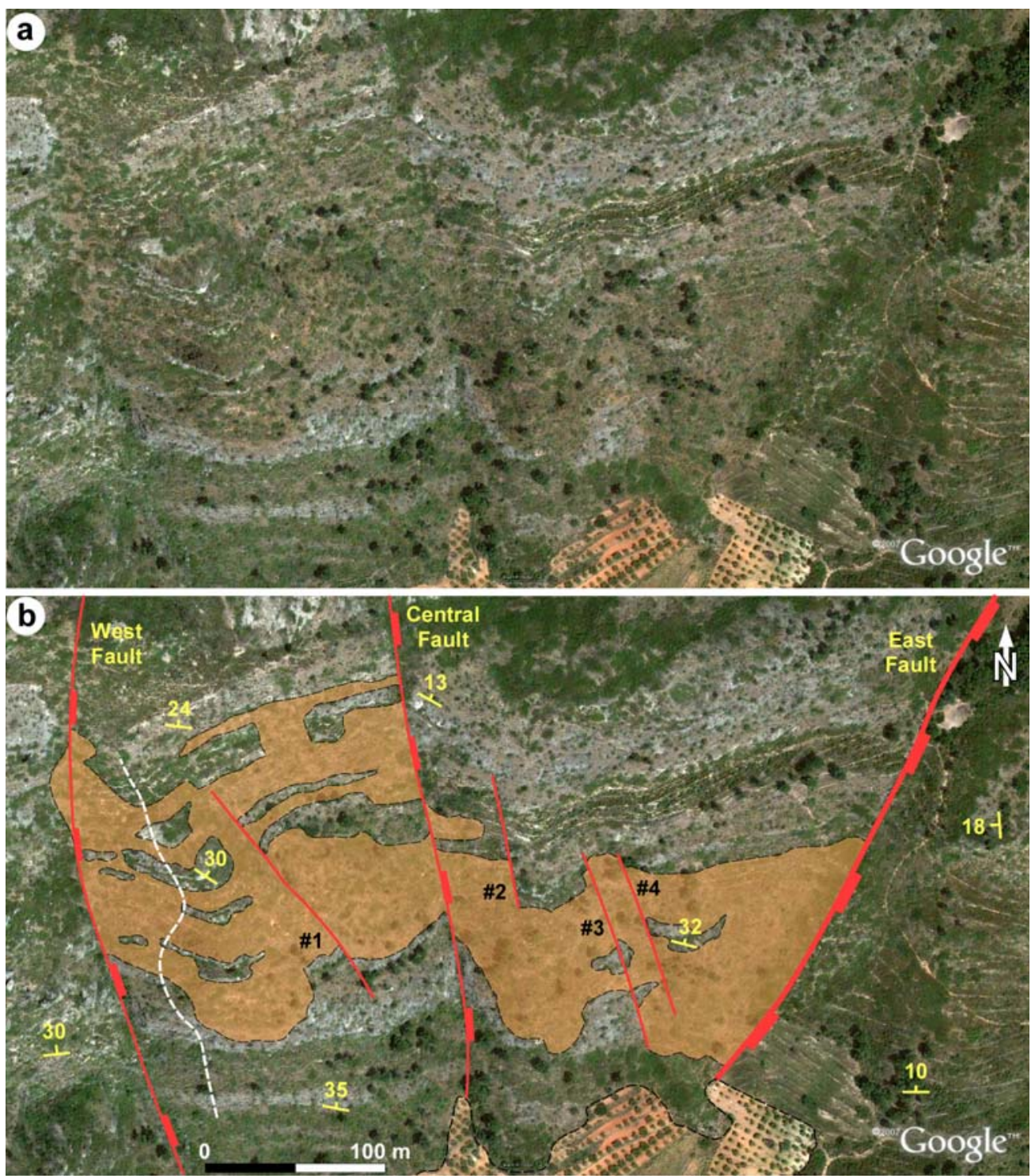

Fig. 4. Raw Google Earth image of the study area (a) and interpreted pair (b) showing the distribution of dolostones (brown area) and bounding faults (red lines). Seismic-scale regional faults are noted by thick lines, seismic-scale secondary faults by thin lines and subseismic-scale (outcrop) faults by thin lines without ticks. The white dashed line indicates the trace of the succession $\log$ (see Figure 6 for a close view). 

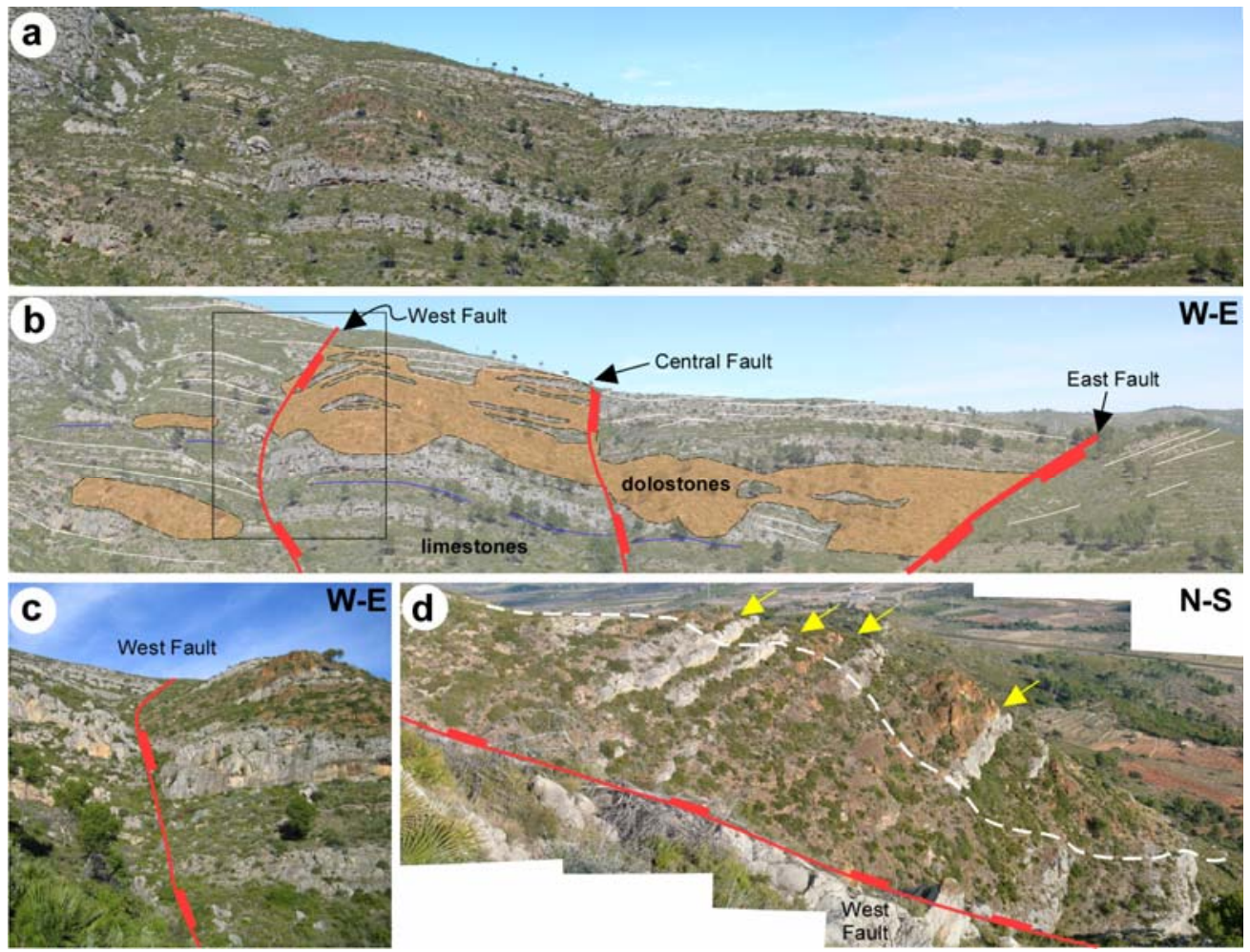

Fig. 5. Field panorama of the study area (a) and interpreted pair (b) showing the relationship between dolostones (brown), limestones (grey) and faults (red lines). Note that outcrop faults of Fig. 4 are here not shown. (c) Close view of B showing the trace of the West Fault marked by a gully. (d) Field view of the hanging wall block of the West bounding Fault showing the trace of the field section (white dashed line) and the predominantly stratabound geometry of the dolostones away from the fault zone. Note the sharp and bed-parallel dolomitization fronts (arrows) constituted by stylolites and bedding planes.

\section{Stylolite types and spacing}

The type and spacing of bed-parallel stylolites varies in the study area depending on whether the facies are muddy or grainy. Stylolites are particularly abundant in mud and coarsesized bioclasts facies (Fig. 6a). The mud-dominated rudist and Chondrodonta floatstones to boundstones that appear at the bottom of the succession are characterized by diffuse bedding planes and swarms of stylolites in a manner similar to that of a fitted fabric (see Tucker \& Wright 1990; p. 359) (Fig. 6b). Stylolites frequently follow the edge of the cm-sized rudist fragments, connecting them and forming stylolite swarms that configure a nodular-like bedding texture. These stylolites are typically spaced between 2 and $5 \mathrm{~cm}$, and show amplitudes in the range of $\mathrm{cm}$. When these beds contain minor coarse bioclasts, usually at the top of the bed sets, stylolites within them are significantly less abundant and the fitted fabric is absent (Fig. 6c).

The mud-dominated coral wackestones located at the middle of the succession are characterized by nodular bedding with a nodular texture enhanced by pressure-solution surfaces, resulting in a network of amalgamated stylolites with a wavy morphology (i.e., wave-like stylolites after Alsharhan \& Sadd 2000) (Fig. 6d). These stylolites are spaced between 15 and 20 $\mathrm{cm}$, and show amplitudes in the range of $\mathrm{cm}$. 
The grain-dominated peloidal, and peloidal and orbitolinid packstones to grainstones that are dominant in the second half of the succession are characterized by well-bedded strata with bed-parallel stylolites (Fig. 6e), which are spaced between 10 and $20 \mathrm{~cm}$, and show amplitudes in the range of $\mathrm{mm}$. Dolostones formed by the replacement of these facies contain traces of the original stylolites with spacing and amplitudes comparable to those in the grain-dominated limestones (Figs 6f).

\section{Post-dolomitization corrosion and cementation}

The replacive dolostones are corroded and contain abundant and irregularly distributed pores that are partially to completely filled with saddle dolomite and calcite cements (Fig. 7). Typically, the pores and cements increase in abundance towards the N-S-striking West bounding Fault. Contrary to the dolostones, the limestones are not affected by this corrosion event, indicating that the corrosion fluid exclusively flowed through the dolostone pore system once out of the faults. The pores in the dolostones are typically elongated, sometimes vug-shaped, and are mainly aligned parallel to the bedding, and thus perpendicular to the faults. They range in thickness from few $\mathrm{mm}$ to several $\mathrm{cm}$, and occasionally reach lengths of several meters (Fig. 7). Field observations indicate that most of these elongated pores are bed-parallel stylolites and bedding planes enlarged by dissolution, but also dissolution-enlarged intercrystal and fracture porosity.

Saddle dolomite (Sd) commonly rim the bed-parallel stylolitic, intercrystal and fracture and vuggy pores (Fig. 7a-e). Saddle dolomite is light yellow in colour in fresh rock and frequently difficult to discern from the host dolostones on outcrop surfaces due to weathering. Blocky calcite cement $(\mathrm{BCc})$ occurs as white and coarse crystals that completely fill the remaining bedparallel pores after saddle dolomite rims (Figs $7 \mathrm{f}-\mathrm{i}$ ). The $\mathrm{BCc}$ calcite cement frequently engulfs $\mathrm{cm}$-sized clasts of both the saddle dolomite and the host dolostones. Sometimes the saddle dolomite rim is absent and the coarse crystalline calcite cement completely fills the pores (Figs $7 \mathrm{j}-1)$.

\section{Petrography of dolostones and cements}

Dolostones are formed by a tight replacive dolomite (Rd) crystal mosaic showing transitional planar-s to nonplanar textures (Figs 8a-b). Replacive dolomite crystals have a polymodal size distribution varying from very fine to very coarse (100 to $1200 \mu \mathrm{m})$. Dolomite crystals are inclusion rich and show straight to slightly wavy extinction with a dull red cathodoluminescence character. Replacive dolomite replaces matrix, grains and early cements in bioclastic and peloidal packstones to grainstones, mainly preserving the primary texture (i.e., producing a mimetic replacement) (Fig. 8c). 
Martin-Martín et al., in press. Activation of stylolites as conduits for overpressured fluid flow in dolomitized platform carbonates. Geological Society of London Special Publication

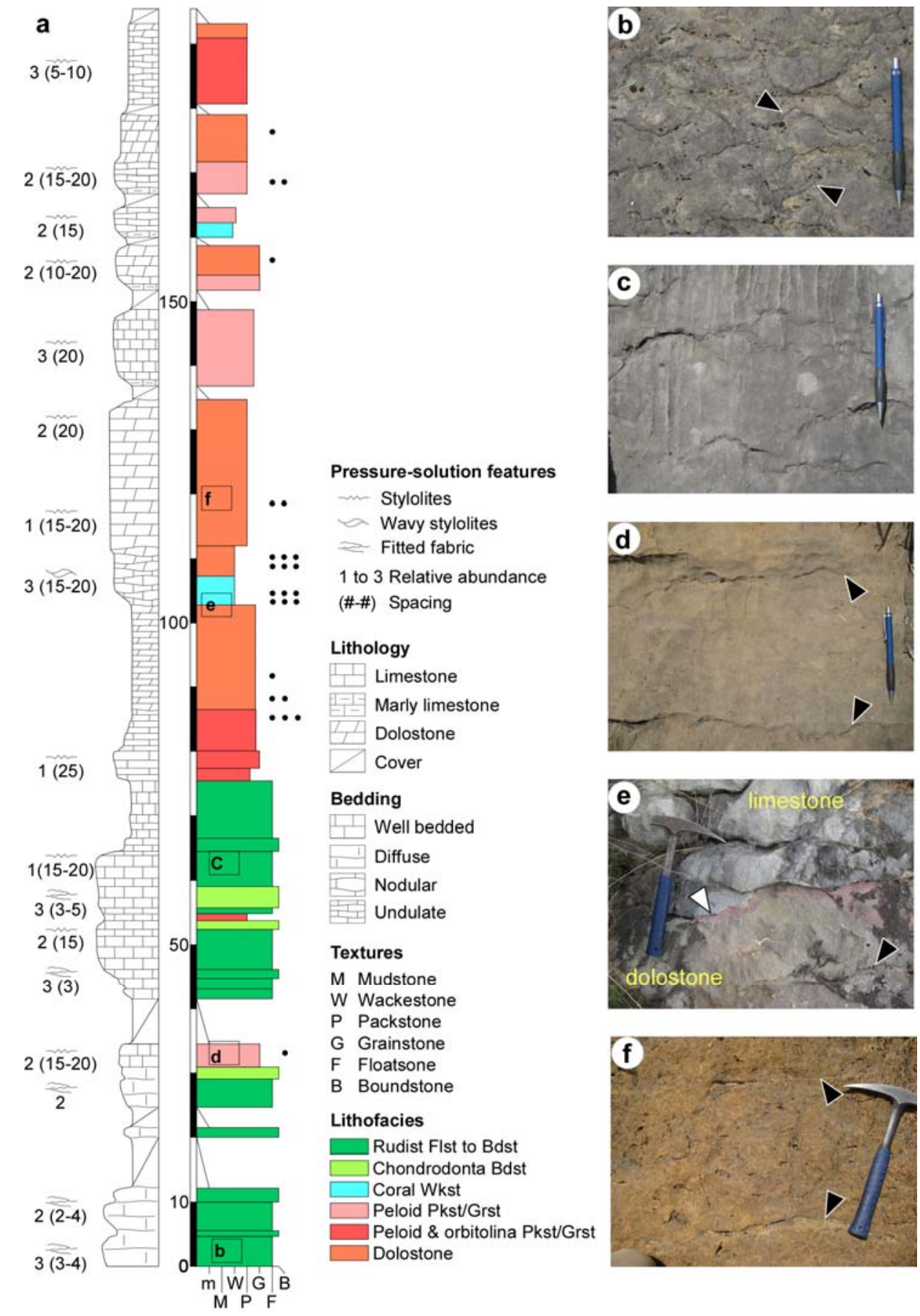

Fig. 6. (a) Field section showing the distribution of limestone facies and dolostones along the hanging wall block of the western bounding fault (see Figs. $4 \mathrm{~b}$ and $5 \mathrm{~d}$ for location). (b) Rudist floatstone to rudstone with amalgamated stylolites showing an overall fitted fabric. Note the coarse sized rudist fragments (arrows). (c) Rudist floatstone on a top bed set showing minor stylolites compared to those reported in a. (d) Peloid packstone to grainstone showing fully bed-parallel stylolites. (e) Partially replaced coral wackestone showing wavy stylolites that form the dolomitizing front. Note that the wavy morphology is recognized in both the limestones and the dolostones indicating a pre-dolomitization formation of the stylolites. (f) Dolostone replacing a grainy limestone facies showing traces of the original bed-parallel stylolites. Note that these stylolitic surfaces are very similar to those reported in $\mathrm{d}$. 
Martin-Martín et al., in press. Activation of stylolites as conduits for overpressured fluid flow in dolomitized platform carbonates. Geological Society of London Special Publication
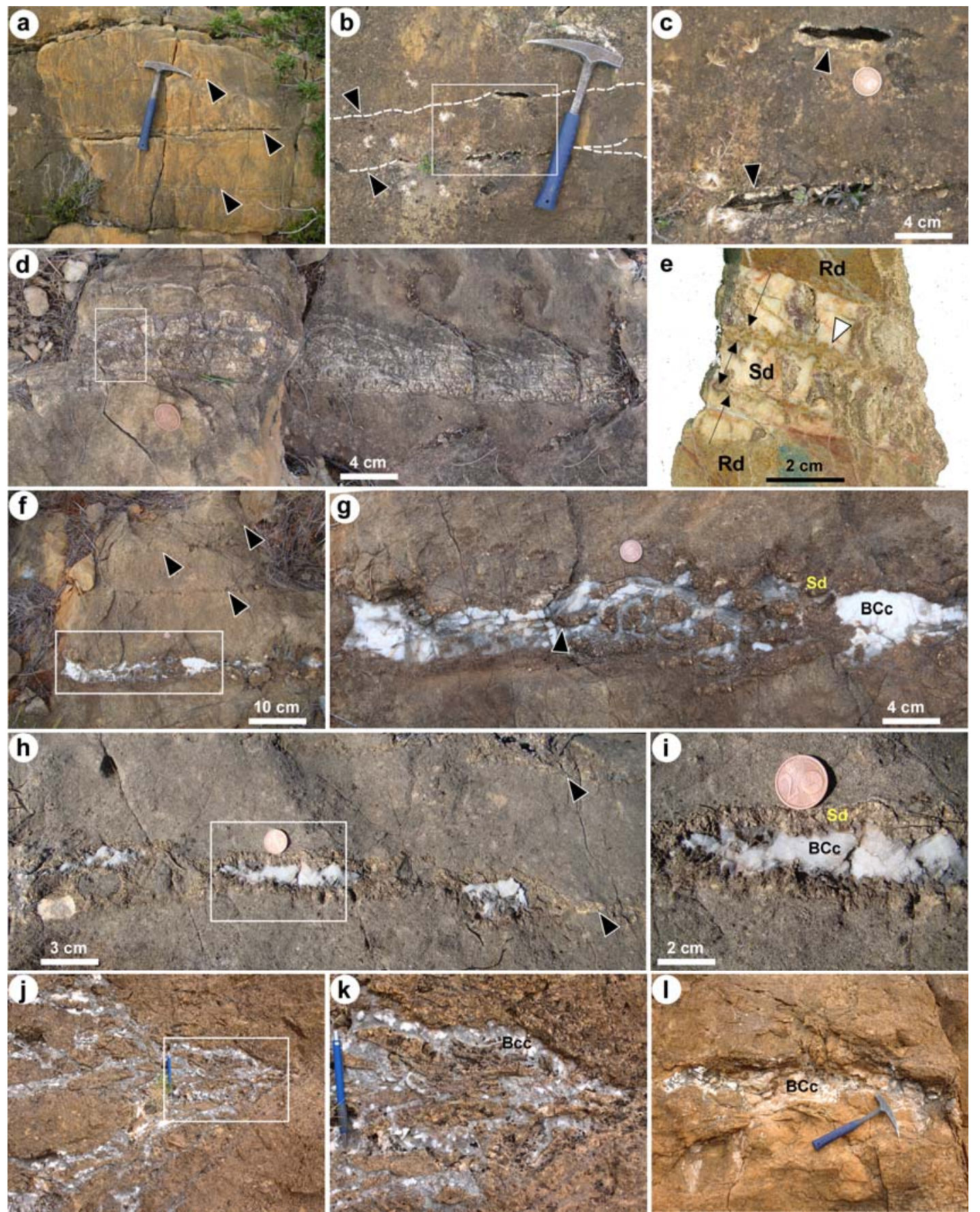

Fig. 7. Field images of dolostones showing post-replacement saddle dolomite and blocky calcite cement in bedparallel pores. (a) Dolostone bed with saddle dolomite rimming successive stylolites (arrows) enlarged by dissolution. (b) Saddle dolomite rimming stylolitic porosity (arrows) and oversized vuggy pores. (c) Detail of B showing the saddle dolomite rims (arrow) and remaining open pores; (d) Bedding parallel cm-thick band of saddle dolomite formed by several fracture fillings. (e) Polished slab (white square in d) showing sharp boundaries between replacive dolomite $(\mathrm{Rd})$ crystal mosaic and saddle dolomite $(\mathrm{Sd})$. Note the two generations of saddle dolomite fillings and the typical curved shape of the saddle dolomite crystals (arrow) towards the centre of the pore. (f) Dolostone bed with four bed-parallel pores, the upper three rimmed with saddle dolomite and the lower one (square) with saddle dolomite and coarse crystalline calcite cement (arrows). (g) Detail of (f) showing coarse-crystalline 
Martín-Martín et al., in press. Activation of stylolites as conduits for overpressured fluid flow in dolomitized platform carbonates. Geological Society of London Special Publication

calcite cement engulfing saddle dolomite clasts. Note that the amount of saddle dolomite (dark brown) is higher than in the upper three pores. (h) Bed-parallel pores (arrows) filled with saddle dolomite and coarse crystalline calcite cement. (i) Detail of (h) showing the textural relationship between the dolomite, saddle dolomite (Sd) and coarse crystalline calcite cement. ( $\mathbf{j}$ and $\mathbf{k}$ ) Meter-scale breccia composed of coarse crystalline calcite cement engulfing dolomite clasts. The pen is $14 \mathrm{~cm}$ long. (l) Very large vug with irregular walls and filled with coarse crystalline calcite probably resulting from the enlargement of stylolitic porosity $(\mathrm{BCc})$.
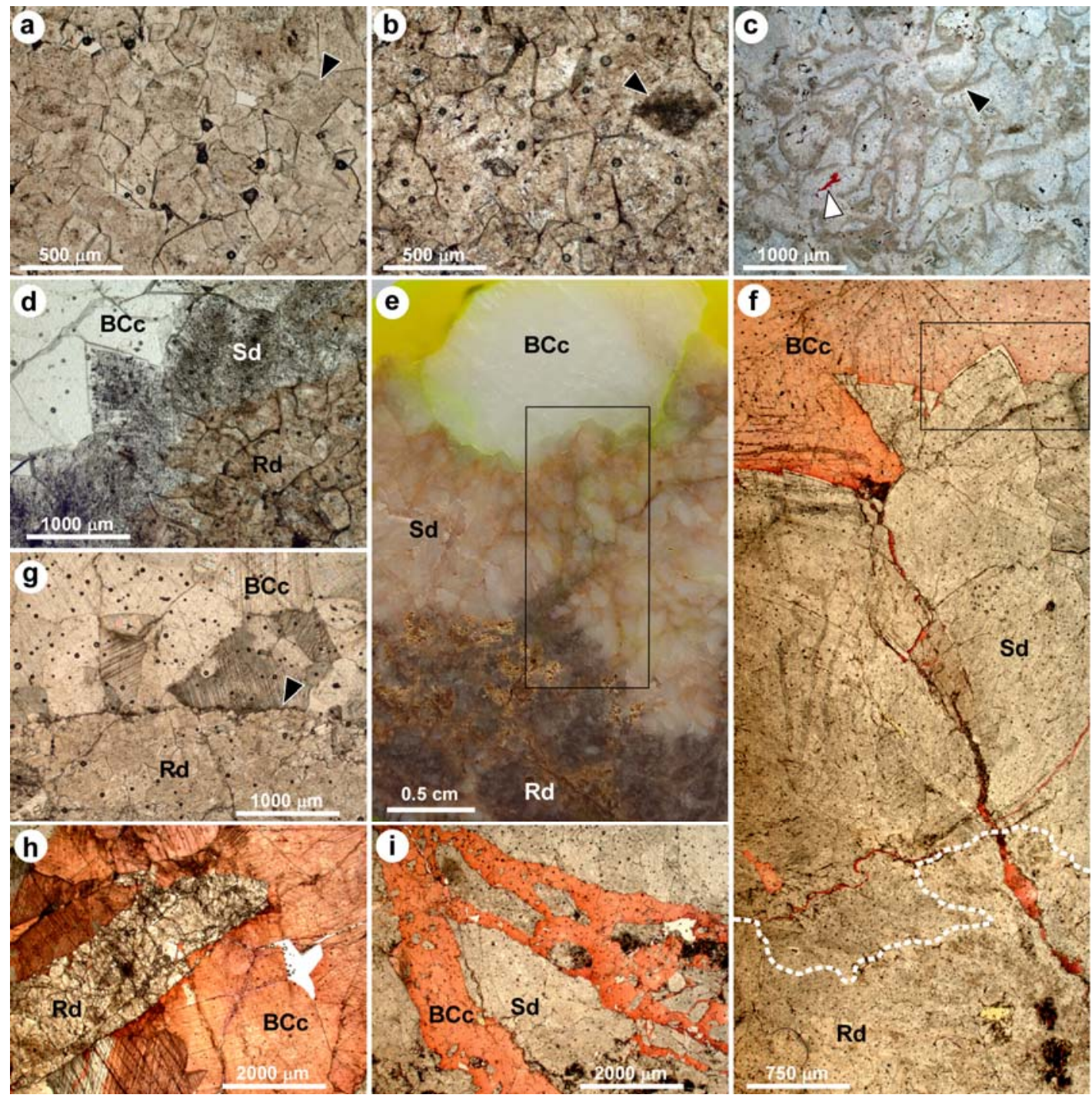

Fig. 8. Photomicrographs of saddle dolomite and blocky calcite cements. (a) Replacive dolomite crystal mosaic showing planar-s to nonplanar textures. (b) Replacive dolomite crystal mosaic showing inclusion rich crystals and ghosts of the original components (arrow). (c) Replacive dolomite crystal mosaic showing ghosts of the original grain components (diffuse light). Note the concavo-convex contacts between grains (arrow) indicating a postcompaction burial replacement (stained). (d) Saddle dolomite crystal (Sd) growing to the centre of a mold that resulted from the dissolution of a coral fragment. The remaining porosity is filled with calcite cement (BCc). (e) Polished slab showing the transition from Rd to Sd crystal mosaics, and from Sd to BCc crystal mosaics. Note that the edge of the Sd mosaic was partly dissolved prior to BCc formation. (f) Photomicrograph of (e) showing the textural relationship between Rd, Sd and BCc (stained). (g) Etched Rd crystal mosaic postdated by BCc, indicating dissolution of the former prior to calcite cementation. (h) BCc crystal mosaic engulfing fragments of the dolostone host rock (Rd) (stained). (i) BCc crystal mosaic engulfing fragments of Sd crystal mosaics (stained). 
Saddle dolomite ( $\mathrm{Sd}$ ) develops as continuous rims along the walls of dissolution-enlarged stylolitic, fracture and meso- to macro-scale vuggy porosity in dolostones (Figs 8d-f). The Sd rim is made of blade-shaped crystal mosaics with individual crystals exhibiting nonplanar textures and typical curved crystal faces. The crystal size varies between $500 \mu \mathrm{m}$ and $4 \mathrm{~mm}$. Sd displays a dull red to brown cathodoluminescence character. In hand specimen it is white to pale orange. Coarse crystalline blocky calcite cement $(\mathrm{BCc})$ occurs as subhedral crystals ranging in size from $100 \mu \mathrm{m}$ to $6 \mathrm{~mm}$ (Figs 8e-i). The BCc displays a zoned dull to bright orange cathodoluminescence character. Frequently, Rd and Sd crystal mosaics show etched margins indicating a dissolution event prior to BCc formation (Fig. 8g).

\section{Carbon-oxygen isotopes}

The micritic matrix of the carbonates cropping out in the La Ferradura area show a $\delta^{18} \mathrm{OVPDB}$ value of $-4.21 \%$ and a $\delta{ }^{13} \mathrm{CVPDB}$ value of $+4.5 \%$ (Fig. 9), which is a signature very close to the isotopic composition of Lower Cretaceous marine carbonates (see Allan \& Wiggins 1993). The replacive dolomite (Rd) yields $\delta^{18} \mathrm{OV}$-PDB values ranging between $-10.1 \%$ and $-7.8 \%$, and $\delta^{13} \mathrm{C}_{\text {VPDB }}$ values between $+2.3 \%$ and $+4.1 \%$ (Fig. 9)

The saddle dolomite (Sd) $\delta^{18} \mathrm{OVPDB}$ values range from $-9.6 \%$ to $-7.9 \%$, and the $\delta^{13} \mathrm{CVPDB}$ values range from $+1.7 \%$ to $+2.4 \%$ o (Fig. 9). Finally, the blocky calcite (BCc) cement yielded $\delta^{18} \mathrm{OvPDB}$ values ranging from $12.8 \%$ to $-8.8 \%$ and $\delta^{13} \mathrm{CVPDB}$ values from $-1.1 \%$ to $+2.6 \%$.

\section{DISCUSSION}

\section{Seismic to subseismic scale controls on dolomitization}

Faults, fractures and permeable strata are commonly claimed to be preferential pathways for fluid flow during the burial dolomitization of carbonate platforms (Davies \& Smith 2006; Wilson et al. 2007; Sharp et al. 2010). Field observations at the La Ferradura outcrop show a clear spatial association of the dolostones and the N-S striking fault system (Figs 4-5). In particular, the West Fault was an efficient barrier for cross-fault circulation of Mg-rich fluids at the time of replacement, constraining these fluids to only the hanging wall block. The primary feeder of the dolomitizing fluids was the regional E-W Campello Fault (Martín-Martín et al. 2015), which is oblique and likely connected to the $\sim \mathrm{N}-\mathrm{S}$ striking fault system (Fig. 10). This fault network is assumed to have favoured the compartmentalization of the carbonate platform and to have focused dolomitizing fluids out of the seismic-scale feeding faults along specific stratigraphic intervals of the Benassal Fm. The association between dolostones and faults in the La Ferradura together with the presence of sharp dolomitization fronts is interpreted to result from a burial, high-temperature replacement process (Figs 4-5; see Warren 2000; Machel 2004; Davies \& Smith 2006). This is supported by the overall negative $\delta^{18} \mathrm{OVPDB}_{\text {visotope values of }}$ replacive dolostones (average of -9.15\%; Fig. 9) (see Allan \& Wiggins 1993). 


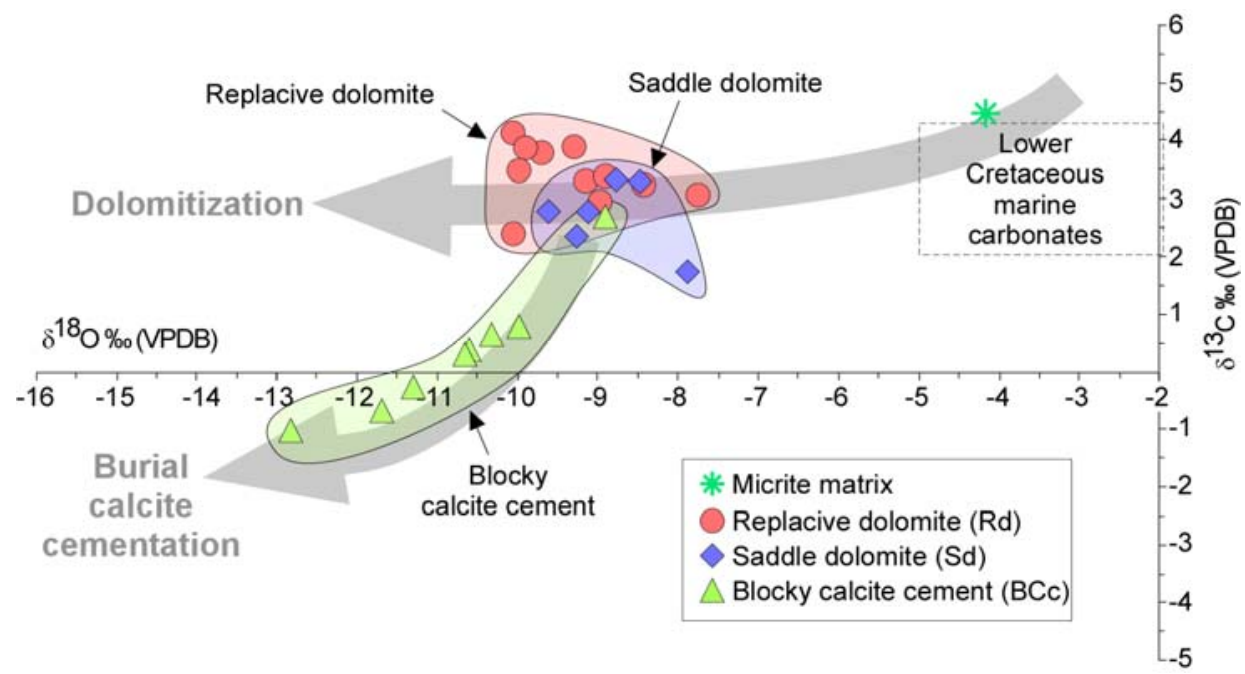

Fig. 9. Oxygen vs carbon isotope cross-plot showing the isotopic composition of the host limestones (micrite matrix) and diagenetic dolomite and calcite phases from the study area. Lower Cretaceous marine carbonates signature according to Allan \& Wiggins (1993).

Field observations from La Ferradura indicate that dolomitization fronts mostly correspond to bed-parallel surfaces such as stylolites and bedding (Figs 5d-6a), suggesting that these surfaces acted as baffles for fluid flow across beds at time of replacement. A predolomitization onset of stylolitization is supported by (1) ghosts of the stylolite traces and remnants of the stylolite clay seams in mimetic replacive dolomite crystal mosaics (Fig. 2) and (2) very similar stylolite geometry and distribution in limestones and their dolomitized counterparts. According to the local burial curve in Fig. 2, the dolomitization of the Benassal Fm took place between 400 and $700 \mathrm{~m}$, and thus the onset of the stylolitization likely started at relatively shallow burial in the studied succession. This is in agreement with the range of burial depth $(300$ to $800 \mathrm{~m}$ ) reported in the literature for the formation of bed-parallel stylolites in limestones (Dunnington 1967; Nicolaides \& Wallace 1997; Ebner et al. 2008). In addition to bed parallel surfaces, the presence of abundant outcrop-scale (i.e., subseismic) faults seems to have notably influenced the location of limestone stringers within the dolostone body, and thus partially control the circulation of Mg-rich fluids between the N-S striking faults (Figs 4-5).

\section{Post-dolomitization opening, corrosion and cementation of stylolites}

Field observations from La Ferradura provide evidence for a close spatial association between bed-parallel pores in dolostones and the N-S striking fault network (Figs 7-11). The bed-parallel pore system represents pre-dolomitization planes such as stylolites and bedding, indicating a preferential opening and subsequent dissolution along them by corrosive fluids sourced from the nearby faults. We interpret that during the corrosion and cementation events, stylolites reversed their role in organizing fluid flow and became preferred pathways for fluids, which further enhanced their permeability parallel to bedding as corrosion increased their stylolite-parallel permeability (Fig. 11). These pores are preferentially found in dolostones replacing grainy limestone facies due to the presence of less amalgamated stylolite planes that facilitated the opening and access for fluids (Figs 6-11). Stylolite and, therefore, bed-parallel 
permeability was also enhanced by fracturing and hydraulic brecciation (Fig. 11), which resulted in saddle-dolomite clasts embedded in late stage calcite (Figs 7h-i, 11). Both fracturing and hydraulic brecciation indicate that the fluids were overpressured (Jébrak 1997; Weisheit et al. 2013): fluid pressure minus overburden pressure exceeded the tensile strength. Stylolites acted as baffles before, probably because insoluble residue on their surface rendered them less permeable. However, these same residues may also reduce their tensile strength, making the stylolites more prone to break once overpressured fluids infiltrate the system. It is worth mentioning that these processes do not result in the development of zebra dolomites in the study area, contrarily to the Basque-Cantabrian Basin by Swennen et al. (2012). The presence of braided networks of, formerly open, cemented stylolites expanding out from outcrop-scale faults (such as those in Figs $7 \mathrm{j}-\mathrm{k}$ ), suggests that they formed as fractures propagating in multiple branches due to high fluid pressure, and following stylolite and bedding planes. Hydraulic fracturing and subsequent corrosion enabled infiltration of further overpressured high-temperature fluids that precipitated the saddle dolomite $(\mathrm{Sd})$ and late calcite cements $(\mathrm{BCc})$. The irregular shape of some of the pores strongly suggests a corroding hydrothermal fluid (e.g. Swennen et al. 2009; 2012). Corrosion was most likely related to the circulation of hot acidic fluids preceding the emplacement of the MVT deposits, which is a typical alteration affecting dolostones (e.g. Gregg 2004; Davies \& Smith 2006) (Fig. 11). Additional evidence of a hot hydrothermal fluid circulation is provided by the presence of saddle dolomite cement (e.g. Spötl \& Pitman 1998) and by the high homogenization temperatures (up to $190^{\circ} \mathrm{C}$ ) from fluid inclusions in BCc (Martín-Martín et al. 2015).

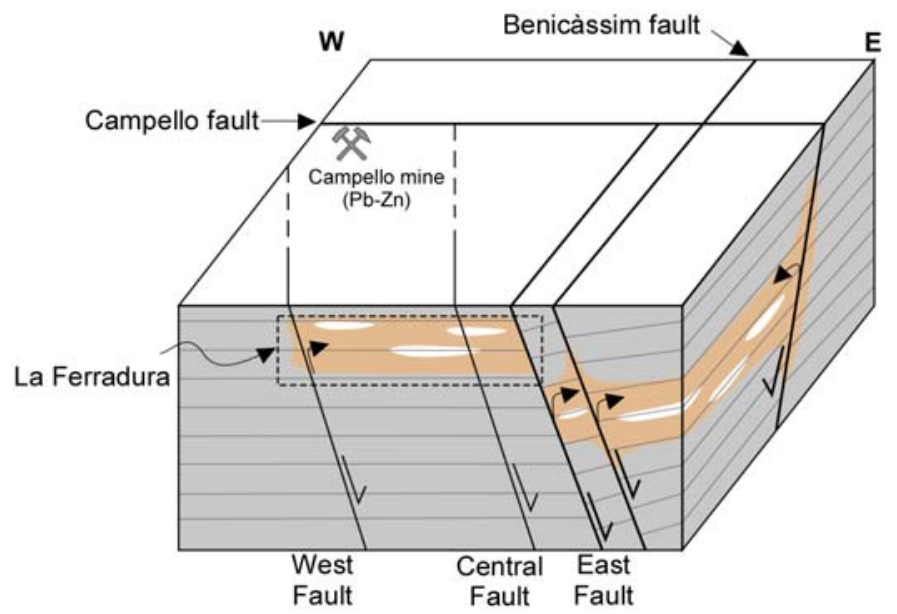

Fig. 10. Block diagram showing the relation between seismic-scale regional faults (thick lines), seismic-scale faults (dashed lines) and dolostone (orange) in the Benicàssim area (not to scale). The arrows indicate major fluid flow during the dolomitization of the Benassal Fm. See Fig. 1c for location.

\section{Potential mechanisms of overpressured fluid flow}

Saddle dolomite and blocky calcite cements are more abundant at La Ferradura than in nearby outcrops of the Benicàssim area (see Martín-Martín et al. 2015). This is interpreted to be a result of the proximity of the studied area to the intersection of the two regional seismic-scale faults (Campello and Benicàssim Faults) that acted as feeders for hot, overpressured fluids from below. Assuming a geothermal gradient of $30^{\circ} \mathrm{C} / \mathrm{km}$ and no cooling during ascent, fluids of up to 
$190^{\circ} \mathrm{C}$ (see Geological Setting) are expected to have derived from a depth of at least about $6 \mathrm{~km}$ if an external source of heat is not invoked. The large faults, which may penetrate up to $15 \mathrm{~km}$ depth (Antolín-Tomas et al. 2007), are the most likely conduits to rapidly bring such fluids to near-surface levels, as otherwise they would have quickly cooled to ambient temperatures (e.g. Bons 2001; Connolly \& Podladchikov 2013).

Several mechanisms can be invoked to deliver high-temperature fluids at shallow crustal levels. A large-scale pervasive fluid circulation system driven by topography or thermal convection can carry large amount of hot fluids along discharge faults (e.g. Matthai et al. 2004; Oliver et al. 2006; Person et al. 2007). However, such a system can only work when the fluid pressure gradient is close to hydrostatic. Otherwise, fluids will not be delivered at high pressures (see discussion in Bons et al. 2012; Bons \& Gomez-Rivas 2013; Bons et al. 2014). Alternatively, other mechanisms that can account for the release of overpressured and hot fluids from below are: (a) fluids resulting from dehydration reactions (e.g. Vry et al. 2010; Weisheit et al. 2014 and references therein), (b) fluids released from crystallizing intrusions (e.g. Smith 1996), and (c) fluids released by heating or by decompression, the latter being associated with exhumation or an extensional stress field (e.g. Staude et al. 2009). The geochemistry of the hydrothermal fluids in Benicàssim and other parts of the Maestrat Basin rules out the possibility that they were derived from dehydration reactions or are of magmatic origin (Gomez-Rivas et al. 2014b).

Taking into account these observations, only the decompression or heating mechanisms (mechanism b and c) appear to have been able to release the high-temperature fluids that produced the post-dolomitization hydrothermal alteration near the large-scale faults at Benicàssim. In the first case, pore-fluid overpressure develops when a rock is decompressed due to, for example, exhumation or an extensional stress field. Exhumation reduces lithostatic pressure by a reduction of the overburden load, while extensional stress reduces the mean stress and therefore pressure. Decompression can release fluids because they are about ten times more compressible than their host rocks (Staude et al. 2009). If a rock decompresses, its volume increase is negligible, and therefore the pore fluid pressure remains the same. If a pore fluid is in equilibrium with the host rock and decompression takes place, the fluid will become out of equilibrium. In such a situation, part of the fluid has to be released in order for the system to regain equilibrium. This "excess volume" of fluid can flow upwards along mobile hydrofractures in quick and localized fluid flow pulses (e.g. Bons 2001; Sachau et al. 2015). This mechanism has been used to explain the formation of ore deposits (Bons et al. 2014) and the development of massive hydraulic breccias (Weisheit et al. 2013). Another mechanism that can release overpressured fluids is their thermal expansion associated with heating. This takes place when rocks and their pore fluids are heated, and the excess volume of trapped fluid results from the higher thermal expansion of the fluid compared to that of the host rock. If the pore system is not well connected, such as in relatively deep levels of the Earth's crust (Ingebritsen \& Manning 1999), pore fluids then become overpressured with respect to the host rocks and may be released upwards by hydrofracturing in order for the system to regain equilibrium. Hydrofracturing causes a sudden increase in permeability, which allows rapid ascent of fluids (Bons 2001). A rapid ascent in required for the fluids to maintain an elevated temperature relative to the surrounding host rock (Connolly 1997). The rapid flow quickly dissipates the overpressure and, 
therefore any drive for further fast flow and hydrofracturing. Fast flow thus occurs in short pulses (Sachau et al. 2015).

Burial curves in the Benicàssim and adjacent areas do not indicate exhumation of relatively shallow rocks during the Late Cretaceous or early Paleocene (Bover-Arnal et al. 2010; Martín-Martín et al. 2015). However, exhumation of deeper rocks could occur in extensional tectonic settings if the crust is being thinned, in a way that the surface of the crust goes down while the Moho moves up. Therefore, rocks below a neutral level can be exhumed, as was suggested by Staude et al. (2009) for the extensive hydrothermal activity during Jurassic basin development in the German Black Forest. The area experienced rifting phases in the Mesozoic (Salas \& Casas 1993; Salas et al. 2001) and in the Late Cretaceous-early Palaeocene (e.g. Meléndez et al. 1985). The latter extensional phase could have resulted in the release of postdolomitization hydrothermal fluids by a combination of a reduced mean stress and decompression at deeper crustal levels. Thermal expansion associated with heating could have taken place if the geothermal gradient of the Maestrat Basin was increased by thinning of the crust during this rifting (Fig. 2) or by the presence of a heat source such as an igneous intrusion (Salas et al. 2005). In any case, anomalous temperatures could have resulted in the heating of trapped basement fluids, therefore producing their thermal expansion and sudden release along faults and mobile hydrofractures in fast pulses. Such pulses could have delivered hot fluids at relatively high pressures to open the stylolites and produce brecciation.

\section{Impact on basin-scale fluid flow}

The results presented in this study, together with those from the same area already reported in the literature (Martín-Martín et al. 2013; Corbella et al. 2014; Gomez-Rivas et al. 2014b; Martín-Martín et al. 2015), indicate that the opening of the stylolite network and the circulation of corrosive and calcite-saturated hydrothermal fluids occurred throughout the complete Benicàssim area. Therefore, these diagenetic alterations and the related fluid circulation affect the complete dolostone exposures and operated in a minimum area of $\sim 14 \mathrm{~km}^{2}$. Regarding the extent and distribution of such alterations, the following key issues can provide predictive rules in reservoirs with similar conditions: (1) the circulation of these fluids exclusively affects dolostones and thus result in lithology-selective diagenetic products (i.e. corrosion and hydrothermal dolomite and calcite cementation), (2) these products are more abundant in the vicinity of faults and fractures, providing an essential rule for predicting similar alterations in real reservoirs, (3) the alterations preferentially affect grain-dominated facies, being mud-dominated facies characterized by swarms of stylolites rarely altered. The example reported here shows how the same stylolites can act both as baffles and conduits for fluid flow during the diagenetic evolution of carbonate successions, thus having a significant impact on their reservoir quality. Therefore, stylolite-related diagenesis has to be carefully addressed when evaluation reservoir quality, since stylolites are ubiquitous in most hydrocarbon carbonate reservoirs (e.g., Pagoni et al. 2015; Ehrenberg et al. 2016). 
Martin-Martín et al., in press. Activation of stylolites as conduits for overpressured fluid flow in dolomitized platform carbonates. Geological Society of London Special Publication

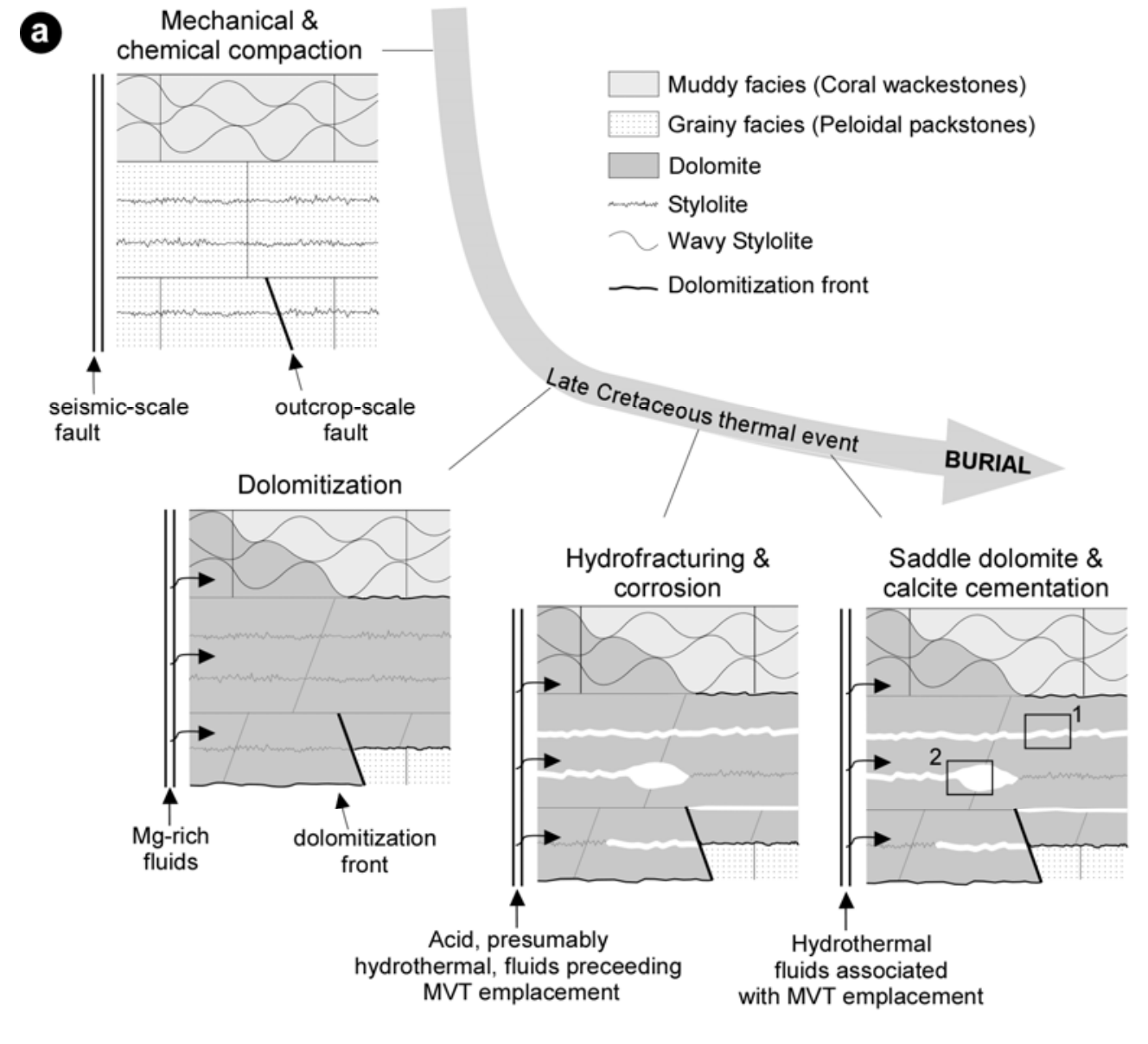

b

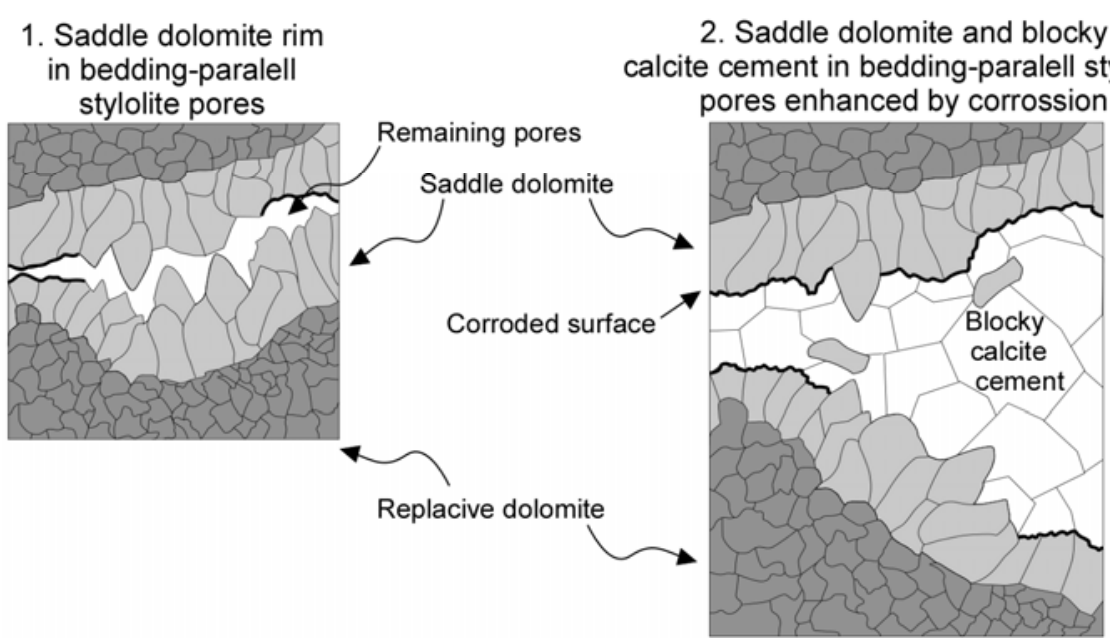

Fig. 11. (a) Sketch showing the major diagenetic events affecting the Benassal Fm during burial. (b) Sketch showing the distribution of saddle dolomite and blocky calcite cement in the bedding parallel pore system. 


\section{CONCLUSIONS}

Field and analytical data from newly studied exposures in the Benicàssim area (Maestrat Basin, Spain) indicate that stylolites played a key role in the dolomitization of the Benassal Fm limestones and the subsequent burial alteration of the dolostones. During the dolomitization process, the pre-replacement stylolitic and bedding surfaces played a key role acting as baffles for fluid flow across beds as indicated by their common occurrence as dolomitization fronts. It is suggested that the stylolite network enhanced the lateral fluid flow and the stratabound character of the dolostones bodies out of the fault zones.

Following dolomitization of the Benassal Fm limestones an important corrosion event took place likely associated with the flux of acid and hydrothermal fluids preceding the emplacement of the MVT deposits. Dissolution fluids were sourced from seismic-scale faults, which are connected to regional feeder faults, and from there they circulated preferentially through outcrop-scale fractures and reactivated bed-parallel stylolites and bedding surfaces. This hydrothermal circulation resulted in (1) the enlargement of dolostone stylolitic, fracture and intercrystalline pore system, and (2) the cementation by saddle dolomite and blocky calcite cement. The opening of the stylolite is mostly attributed to the presence of overpressured fluids as indicated by the presence of hydrothermal breccias and clasts of the host dolostones engulfed by the blocky calcite cement. This corrosion and cementation event is recorded in the dolostones only, which is linked to the mechanical contrast with the limestones.

Results reveal that stylolite networks can act as both barriers and conduits for fluid flow during the burial evolution of platform carbonates, and therefore, highlight the importance of documenting and characterizing such subseismic-scale structures in carbonate reservoirs.

\section{ACKNOWLEDGMENTS}

This research was developed with funding provided by the Spanish Government I+D+I Research Projects CGL2015-69805-P and CGL2015-66335-C2-1-R, and the Generalitat de Catalunya (2014SGR251). The research also benefited from a grant of the Geological Society of London (Elspeth Matthews Fund 2015) to EGR. The authors would like to thank M. Aston and O. P. Wennberg for the editorial work, and F. Laponi and an anonymous reviewer for their critical and constructive comments.

\section{REFERENCES}

Agar, S. M. \& Geiger, S. 2014. Fundamental controls on fluid flow in carbonates: current workflows to emerging technologies. Geological Society, London, Special Publication, 406, 1-59.

Agosta, F., Alessandroni, M., Antonellini, M, Tondi, E. \& Giorgioni, M. 2010. From fractures to flow: a field-based quantitative analysis of an outcropping carbonate reservoir. Tectonophysics, 490, 197-213.

Allan, J. R. \& Wiggins, W. D. 1993. Dolomite reservoirs: Geochemical techniques for evaluating origin and distribution. American Association of Petroleum Geologists Continuing Education Course Notes 36, Tulsa.

Alsharhan, A. \& Sadd J. L. 2000. Stylolites in Lower Cretaceous carbonate reservoirs, U.A.E: Society for Sedimentary Geology Special Publication, 69, 185-207.

Antolín-Tomás, B., Liesa, C. L., Casas, A. M. \& Gil-Peña, I. 2007. Geometry of fracturing linked to extension and basin formation in the Maestrazgo Basin (Eastern Iberian Chain, Spain). Revista de la Sociedad Geológica de España, 20, 351-365. 
Martín-Martín et al., in press. Activation of stylolites as conduits for overpressured fluid flow in dolomitized platform carbonates. Geological Society of London Special Publication

Baqués, V., Travé, A. \& Cantarero, I. 2014. Development of successive karstic systems within the Baix Penedès Fault zone (onshore of the Valèmcia Trough, NW Mediterranean). Geofluids, 14 (1), 75-94.

Ben-Itzhak, L. L., Aharonov, E., Karcz, Z., Kaduri, M. \& Toussaint, R. 2014. Sedimentary stylolite networks and connectivity in Limestone: Large-scale field observations and implications for structure evolution. Journal of Structural Geology, 63, 106-123

Benedicto, A. \& Schultz, R. A. 2009. Stylolites in limestone: Magnitude of contractional strain accommodated and scaling relationships. Journal of Structural Geology, 32, 1250-1256, http://doi:10.1016/j.jsg.2009.04.020

Bons, P. D. 2001. The formation of large quartz veins by rapid ascent of fluids in mobile hydrofractures. Tectonophysics, 336 (1), 1-17.

Bons, P. D., Elburg, M. \& Gomez-Rivas, E. 2012. A review of the formation of tectonic veins and their microstructures. Journal of Structural Geology, 43, 33-62.

Bons, P. D. \& Gomez-Rivas, E. 2013. Gravitational fractionation of isotopes and dissolved components as a firstorder process in crustal fluids. Economic Geology, 108 (5), 1195-1201.

Bons, P. D., Fusswinkel, T., Gomez-Rivas, E., Markl, G., Wagner, T. \& Walter, B. 2014. Fluid mixing from below in unconformity-related hydrothermal ore deposits. Geology, 42, 1035-1038, http://doi:10.1130/G35708.1

Bover-Arnal, T., Moreno-Bedmar, J. A., Salas, R., Skelton, P. W., Bitzer, K. \& Gili, E. 2010. Sedimentary evolution of an Aptian syn-rift carbonate system (Maestrat Basin, E Spain): effects of accommodation and environmental change. Geologica Acta, 8 (3), 249-280.

Caine, J. S., Evans, J. P. \& Forster, C. B. 1996. Fault zone architecture and permeability structure. Geology, 24, 1025-1028.

Carozzi A. V. \& von Bergen D. 1987. Stylolitic porosity in carbonates: A critical factor for deep hydrocarbon production. Journal of Petroleum Geology, 10, 267-282.

Connolly, J. A. D. 1997. Mid-crustal focused fluid movement: thermal consequences and silica transport. In: Jamtveit, B., Yardley, B. W. (eds.), Fluid Flow and Transport in Rocks. Chapman \& Hall, London, 235-250.

Connolly J. A. D. \& Podladchikov Y. Y. 2013. A Hydromechanical Model for Lower Crustal Fluid Flow. In: D.E. Harlov a\&nd H. Austrheim (eds) Metasomatism and the Chemical Transformation of Rock. Lecture Notes in Earth System Sciences. Springer, New York, 599-658, http://doi:10.1007/978-3-642-28394-9 14.

Corbella, M., Gomez-Rivas, E. et al. 2014. Insights to controls on dolomitization by means of reactive transport models applied to the Benicàssim case study (Maestrat Basin, eastern Spain). Petroleum Geoscience, 20 (1), 41-54.

Davies, G. R. \& Smith, L. B. J. 2006. Structurally controlled hydrothermal dolomite reservoir facies: An overview. AAPG Bulletin, 90, 1641-1690.

Davy, P., Bour, O., De Dreuzy, J.-R. \& Darcel, C. 2006. Flow in multiscale fractal fracture networks. In: G., Cello \& B. D., Malamud (eds) Fractal Analysis for Natural Hazards Geological Society, London, Special Publication, 261, 31-45, http://doi:10.1144/GSL.SP.2006.261.01.03.

Dewit, J., Foubert, A., El Desouky, H. A., Muchez, P., Hunt, D., Vanhaecke, F. \& Swennen, R. 2014. Characteristics, genesis and parameters controlling the development of a large stratabound HTD body at Matienzo (Ramales Platform, Basque-Cantabrian Basin, northern Spain). Marine and Petroleum Geology, 55, 6-25.

Dunham, R. J. 1962. Classification of carbonate rocks according to depositional texture. In: W. E. Ham, (ed) Classification of carbonate rocks. American Association of Petroleum Geologists, Memoir 1, Tulsa, 108-121.

Dunnington, H. V. 1967. Aspects of diagenesis and shape in stylolitic limestone reservoirs. In: Origin of Oil, Geology and Geophysics, Proceedings of the $7^{\text {th }}$ World Petroleum Congress, vol. 2, 339-352.

Dutton S. P. \& Willis B. J. 1998. Comparison of outcrop and subsurface sandstone permeability distribution, Lower Cretaceous Fall River Formation, South Dakota and Wyoming. Journal of Sedimentary Research, 68, 890-900, http://doi:10.2110/jsr.68.890.

Ebner, M., Koehn, D., Toussaint, R., Renard, F., Schmittbuhl, J. 2008. Stress sensitivity of stylolite morphology. Earth Planet. Sci. Lett., 277, 394-398.

Ehrenberg, S. N., Liu Yaxin \& Morad, S. (2016). Stylolites and porosity in a Lower Cretaceous limestone reservoir, onshore Abu Dhabi. Search and Discovery Article, \#51248.

Embry, A. F. \& Klovan, J. S. 1971. A Late Devonian reef tract on northeastern Banks Island, N.W.T. Bulletin of Canadian Petroleum Geology, 4, 730-781.

Finkel E. A. \& Wilkinson B. H. 1990. Stylolitization as source of cement in Mississippian Salem Limestone, westcentral Indiana. AAPG Bulletin, 74, 174-186. 
Martín-Martín et al., in press. Activation of stylolites as conduits for overpressured fluid flow in dolomitized platform carbonates. Geological Society of London Special Publication

Garcia, R., Moreno-Bedmar, J. A. et al. 2014. Lower Cretaceous (Hauterivian-Albian) ammonite biostratigraphy in the Maestrat Basin (E Spain). Journal of Iberian Geology, 40(1), 99-112.

Gomez-Rivas, E., Bons, P. D. et al. 2014a. The Jabal Akhdar Dome in the Oman Mountains: evolution of a dynamic fracture system. American Journal of Science, 314, 1104-1139.

Gomez-Rivas, E., Corbella, M., Martín-Martín, J. D., Stafford, S.L., Teixell, A., Bons, P. D., Griera, A. \& Cardellach, E. 2014b. Reactivity of dolomitizing fluids and $\mathrm{Mg}$ source evaluation of fault-controlled dolomitization at the Benicàssim outcrop analogue (Maestrat Basin, E Spain). Marine and Petroleum Geology, 55, 26-42.

Gomez-Rivas, E., Warber, K., Kulzer, F., Bons, P. D., Koehn, D. \& Martín-Martín, J. D. 2012. Structural evolution of the Benicàssim area (Maestrat basin, NE Spain): insights from fracture and vein analysis. Geogaceta, 51, 79-82.

Grandia, F., Asmerom, Y., Getty, S., Cardellach, E. \& Canals, A. 2000. U-Pb dating of MVT ore-stage calcite: implications for fluid flow in a Mesozoic extensional basin from Iberian Peninsula. Journal of Geochemical Exploration, 69-70, 377-380.

Grandia, F., Cardellach, E., Canals, A. \& Banks, D.A. 2003. Geochemistry of the fluids related to epigenetic carbonate-hosted $\mathrm{Zn}-\mathrm{Pb}$ deposits in the Maestrat Basin, Eastern Spain: fluid inclusion and isotope $(\mathrm{Cl}, \mathrm{C}, \mathrm{O}, \mathrm{S}$, Sr) evidence. Economic Geology, 98, 933-954.

Gregg, J.M. 2004. Basin fluid flow, base-metal sulphide mineralization and the development of dolomite petroleum reservoirs. In: Braithwaite, C.J.R., Rizzi, G. \& Darke, G. (eds.), The Geometry and Petrogenesis of Dolomite Hydrocarbon Reservoirs. Geological Society, London, Special Publication, 235, 157-175.

Gross, M. R. \& Eyal, Y. 2007. Throughgoing fractures in layered carbonate rocks. GSA Bulletin, 119 (11-12), 1387 1404, http://doi:10.1130B26049.1

Heap, M. J., Baud, P., Reuschelé, T. \& Merefith, P. G. 2014. Stylolites in limestones: Barriers to fluid flow? Geology, 42 (1), 51-54, http://doi:10.1111/j.1747-5457.1987.tb00946.x

Hilgers, C., Nollet, S., Schoenherr, J. \& Urai, J. L. 2006. Paleo-Overpressure Formation and Dissipation in Reservoir Rocks. Oil and Gas European Magazine, 32(6), 68-73.

Ingebritsen, S.E. \& Manning, C.E. 1999. Geological implications of a permeability-depth curve for the continental crust. Geology, 27 (12), 1107-1110

Jébrak, M. 1997. Hydrothermal breccias in vein-type ore deposits: a review of mechanisms, morphology and size distribution. Ore Geology Reviews, 12, 111-134.

Jones, C. E. \& Jenkins, H. C. 2001. Seawater strontium isotopes, oceanic anoxic events, and seafloor hydrothermal activity in the Jurassic and Cretaceous. American Journal of Science, 301, 112-149.

Koehn, D., Renard, F., Toussaint, R. \& Passchier, C. W. 2007. Growth of stylolite teeth patterns depending on normal stress and finite compaction. Earth and Planetary Science Letters, 257 (3-4), 582-595.

Laubach, S. E., Eichhubla, P., Hilgers, C. \& Landerc, R. H. 2010. Structural Diagenesis. Journal of Structural Geology, 32, 1866-1872.

Liesa, C. L. \& Simón, J. L. 2009. Evolution of intraplate stress fields under multiple remote compressions: The case of the Iberian Chain (NE Spain). Tectonophysics, 474, 144-159.

Liesa, C. L., Soria, A. R., Meléndez, N. \& Meléndez, A. 2006. Extensional fault control on the sedimentation patterns in a continental rift basin: El Castellar Formation, Galve sub-basin, Spain. Journal of the Geological Society, 163(3), 487-498, http://Doi: 10.1144/0016-764904-169.

López-Horgue, M. A., Iriarte, E., Schröder, S., Fernández-Mediola, P. A., Caline, B., Corneyllie, H., Frémont, J., Sudrie, M. \& Zerti, S. 2010. Structurally controlled hydrothermal dolomites in Albian carbonates of the Asón valley, Basque Cantabrian Basin, Northern Spain. Marine and Petroleum Geology, 27 (5), 1069-1092.

Machel, H. G. 2004. Concepts and models of dolomitization: a critical reappraisal. In: Braithwaite, C. J. R., Rizzi, G. \& Darke, G (eds), The Geometry and Petrogenesis of dolomite Hydrocarbon Reservoirs. Geological Society, London, Special Publication, 235, 7-63.

Martín-Martín, J. D., Sanfeliu, T. \& Gómez-Gras, D. 2005. Mineralogía de arcillas cerámicas. El Permo-Trías de Castelló. Publicacions de la Universitat Jaume I, Col·lecció Athenea 13, Castelló de la Plana.

Martín-Martín, J. D., Salas, R. Gómez-Gras, D. \& Zwingmann, H. 2009. K/Ar isotopic dating of very low-grade metamorphic and late diagenetic conditions during the Mesozoic rifting evolution of the Iberian Chain, Spain. In: Fiore, S., Belviso, C. \& Giannossi, M.L. (eds.), XIV International Clay Conference (Italy), Micro et Nano: Scientae Mare Magnum. Associazione Italiana per lo Studio delle Argille, Book of Abstracts, 236. 
Martín-Martín et al., in press. Activation of stylolites as conduits for overpressured fluid flow in dolomitized platform carbonates. Geological Society of London Special Publication

Martín-Martín, J. D., Gomez-Rivas, E. et al. 2013. The Upper Aptian to Lower Albian syn-rift carbonate succession of the southern Maestrat Basin (Spain): Facies architecture and fault-controlled stratabound dolostones. Cretaceous Research, 41, 217-236.

Martín-Martín, J. D., Travé, A. et al. 2015. Fault-controlled and stratabound dolostones in the Late Aptian-earliest Albian Benassal Formation (Maestrat Basin, E Spain): petrology and geochemistry constrains. Marine and Petroleum Geology, 65, 83-102.

Matthäi S. K., Heinrich C. A. \& Driesner T. 2004. Is the Mount Isa copper deposit the product of forced brine convection in the footwall of a major reverse fault? Geology, 32, 357-360, http://doi:10.1130/G20108.1

Meléndez, A., Meléndez, F., Portero, J. \& Ramírez, J. 1985. Stratigraphy, sedimentology and paleogeography of Upper Cretaceous evaporitic-carbonate platforms in the Central part of the Sierra Ibérica. 6th European Regional Meeting. Excursion Guidebook, Lleida, 187-193.

Merino, E. 1992. Self-organization in stylolites. American Scientist, 80, 466.

Moreno-Bedmar, J.A., Company, R., Bover-Arnal, T., Salas, R., Delanoy, G., Maurrasse, F.J.-M.R., Graugés, A. \& Martínez, R., 2010. Lower Aptian ammonite biostratigraphy in the Maestrat Basin (Eastern Iberian Chain, Easter Spain). A Tethyan transgressive record enhanced by synrift subsidence. Geologica Acta, 8 (3), 281-299.

Nelson, R. A. 1981. Significance of fracture sets associated with stylolite zones. American Association of Petroleum Geologists Bulletin, 65, 2417-2425.

Nelson, R. A. 2001. Geologic Analysis of Naturally Fractured Reservoirs. Gulf Professional Publication Company, Boston.

Nicolaides, S. \& Wallace, M. W. 1997. Pressure-dissolution and cementation in an Oligo-tropical limestone (Clifton Formation), Otway Basin, Australia. In: James, N. P., Clarke, J. A. D. (eds.), Cool Water Carbonates, Soc. Econ. Petrol. Geol. Spec. Publ. 56, 249-261.

Oliver, N.,H.,S., McLellan J. G., Hobbs B. E., Cleverley J. S., Ord A. \& Feltrin L. 2006. Numerical models of extensional deformation, heat transfer, and fluid flow across basement-cover interfaces during basin-related mineralization. Economic Geology and Bulletin of the Society of Economic Geologists, 101, 1-31, $\mathrm{http} / /$ doi:10.2113/gsecongeo.101.1.1

Paganoni, M., Al Harethi, A. et al. 2015. Impact of stylolitization on diagenesis and reservoir quality: A case study from an Early Cretaceous reservoir in a Giant oilfield, Abu Dhabi, United Arba Emirates. Society of Petroleum Engineers International, SPE-177944-MS.

Park, W. C. \& Schot, E. H. 1968. Stylolites: their nature and origin. Journal of sedimentary Petrology, 38(1), $175-$ 191.

Person M., Mulch A., Teyssier C. \& Gao Y. 2007. Isotope transport and exchange within metamorphic core complexes. American Journal of Science, 307, 555-589, http//doi:10.2475/03.2007.01

Riding, R. \& Tomás, S. 2006. Bacterial origin of in situ precipitated peloid microspar? stromatolite reef crusts, Early Cretaceous, Spain. Sedimentology, 53, 23-34.

Roca, E. 1996. La evolución geodinámica de la Cuenca Catalano-Balear y áreas adyacentes desde el Mesozoico hasta la actualidad. Acta Geológica Hispánica, 29, 3-25.

Sachau, T., Bons, P. D. \& Gomez-Rivas, E. 2015. Transport efficiency and dynamics of hydraulic fracture networks. Frontiers in Physics, 3, 63, http://dx.doi.org/10.3389/fphy.2015.00063.

Salas, R., \& Casas, A. 1993. Mesozoic extensional tectonics, stratigraphy and crustal evolution during the Alpine cycle of the eastern Iberian basin. Tectonophysics, 228, 33-55.

Salas, R., Guimerà, J., Mas, R., Martín-Closas, C., Meléndez, A. \& Alonso, A., 2001. Evolution of the Mesozoic Central Iberian Rift System and its Cenozoic inversion (Iberian Chain). In: Ziegler, P.A., Cavazza, W., Robertson, A.H.F. \& Crasquin-Soleau, (eds), Peri-Tethyan Memoirs 6: Peritethyan rift/wrench basins and passive margins. Mém. Mus. natn. Hist. nat., 186, 145-185.

Salas, J., Caja, M. A., Mas, R., Martín-Martín, J.D., Mas, R. \& Permanyer, A., 2005. Mid-Late Cretaceous volcanism, metamorphism and the regional thermal event affecting the Northeastern Iberian Basins (Spain). In: Arnaud-Vanneau, A., Arndt, N., Zghal, I. (eds.), Global events during the quiet Aptian-Turonian superchron. Laboratoire de Géologie de l'Université I de Grenoble, Geologie Alpine, Série Spéciale N 6, Grenoble.

Shah, M. M., Nader, F. H., Dewit, J., Swennen, R. \& Garcia, D. 2010. Fault-related hydrothermal dolomites in Cretaceous carbonates (Cantabria, northern Spain): results of petrographic, geochemical and petrophysical studies. Bulletin de la Société Géologique de France, 181 (49), 391-407.

Sharp, I., Gillespie, P. et al. 2010. Stratigraphic architecture and fracture-controlled dolomitization of the Cretaceous Khami and Bangestan groups: an outcrop case study, Zagros Mountains, Iran. In: van Buchem, F.S.P., Gerdes, 
Martín-Martín et al., in press. Activation of stylolites as conduits for overpressured fluid flow in dolomitized platform carbonates. Geological Society of London Special Publication

K.D., Esteban, M. (eds.), Mesozoic and Cenozoic Carbonate Systems of the Mediterranean and the Middle East: Stratigraphic and Diagenetic Reference Models. Geological Society, London, Special Publications, 329, 343-396.

Skelton, P. W. \& Gili, E. 2012. Rudists and carbonate platforms in the Aptian: a case study on biotic interactions with ocean chemistry and climate. Sedimentology, 59, 81-117.

Smith Jr., D. M. 1996. Sedimentary basins and the origin of intrusion-related carbonate- hosted $\mathrm{Zn}-\mathrm{Pb}-\mathrm{Ag}$ deposits. In: Sangster, D.F. (ed), Carbonate-Hosted Lead-Zinc Deposits. Society of Economic Geologists Special Publications, 4, 255-263.

Spötl, C. \& Piman, J. K. 1998. Saddle (baroque) dolomite in carbonates and sandstones: a reappraisal of a burialdiagenetic concept. In: Morad, S. (ed) Carbonate cementation in sandstones. International Association of Sedimentologists Special Publication 26, 437-460.

Staude, S., Bons, P. D. \& Markl, G. 2009. Hydrothermal vein formation by extension- driven dewatering of the middle crust: An example from SW Germany. Earth and Planetary Science Letters, 286, 387-395.

Stockdale, P. B. 1922. Stylolites: their nature and origin. Indiana University Studies, 9, 1-97.

Swennen, R., Dewit, J., Fierens, E., Muchez, Ph., Foubert, A., Nader, F., Shah, M. \& Hunt, D. 2009. Evidence of repeated hot fluid pulses along the Ranero fault system (Cantabrian Mountains, North Spain). Journal of Geochemical Exploration, 101, 100.

Swennen, R., Dewit, J., Fierens, E., Muchez, Ph., Shah, M., Nader, F. \& Hunt, D. 2012. Multiple dolomitization events along the Pozalagua Fault (Pozalagua Quarry, Basque-Cantabrian Basin, Northern Spain). Sedimentology, 59, 1350-1374.

Tomás, S., Löser, H. \& Salas, R., 2008. Low-light and nutrient-rich coral assemblages in an Upper Aptian carbonate platform of the southern Maestrat Basin (Iberian Chain, eastern Spain). Cretaceous Research, 29, 509-534.

Tritlla, J. \& Sole, J. 1999. A newly dated Cretaceous hydrothermal event in the Iberian Ranges, (Eastern Spain) and its significance within the Mesozoic thermal history in the Iberian Peninsula. Ore Geology Reviews, 15, 243259.

Tritlla, J. \& Cardellach, E. 2003. Ba Hg deposits in the Espadán ranges (Iberian Chain, Eastern Spain): an example of Cretaceous fluid circulation and Alpine overprinting. Journal of Geochemical Exploration, 78-79, 579-584.

Tucker, M. E. \& Wirght, V. P. 1990. Carbonate sedimentology. Blackwell Scientific Publications, Oxford.

Vandeginste, V. \& John, C. M. 2013. Diagenetic implications of stylolitization in pelagic carbonates, Canterbury Basin, offshore New Zealand. Journal of Sedimentary Research, 83(3), 226-240.

Van Geet, M., Swennen, R. \& Wevers, M. 2001. Towards 3-D petrography: Application of microfocus computer tomography in geological science. Computers \& Geosciences, 27 (9), 1091-1099, http//doi: 10.1016/S00983004(00)00154-0

Vry, J., Powell, R., Golden, K. M. \& Petersen, K. 2010. The role of exhumation in metamorphic dehydration and fluid production. Nature Geoscience, 3, 31-35.

Warren, J. 2000. Dolomite: occurrence, evolution and economically important associations. Earth-Science Reviews, $52,1-81$

Weisheit, A., Bons, P. D. \& Elburg, M. A., 2013. Long-lived crustal-scale fluid flow: the hydrothermal megabreccia of Hidden Valley, Mt. Painter Inlier, South Australia. International Journal of Earth Sciences (Geolische Rundschau), 102, 1219-1236, http//doi: 10.1007/s00531-013-0875-7

Weisheit, A., Bons, P. D., Danisik, M. \& Elburg, M. A. 2014. Crustal-scale folding: Palaeozoic deformation of the Mt. Painter Inlier, South Australia. In: Llana-Fúnez, S., Marcos, A. \& Bastida, F. (eds), Deformation Structures and Processes within the Continental Crust. Geological Society, London, Special Publications, 394, http//doi: 10.1144/SP394.9

Wilson, M. I. J., Evans, M. J., Oxtoby, N. H, Nas, D. S. Donnelly, T. \& Thirwall, M. 2007. Reservoir quality, textural evolution, and origin of fault-associated dolomites. AAPG Bulletin, 91(9), 1247-1272. 